OPEN ACCESS

Edited by:

Loretta Tuosto,

Sapienza University of Rome, Italy

Reviewed by:

Daniel Olive,

French Institute of Health and Medical Research, France

Lawrence Kane,

University of Pittsburgh, USA

Haopeng Wang,

ShanghaiTech University, China

*Correspondence:

Sheela Ramanathan

sheela.ramanathan@usherbrooke.ca

$$
\begin{array}{r}
\text { Specialty section: } \\
\text { This article was submitted to } \\
T \text { Cell Biology, } \\
\text { a section of the journal } \\
\text { Frontiers in Immunology }
\end{array}
$$

Received: 20 November 2016

Accepted: 19 January 2017

Published: 07 February 2017

Citation:

Serrano D, Ghobadi F, Boulay G,

llangumaran S, Lavoie C and

Ramanathan S (2017) GTPase of the

Immune-Associated Nucleotide

Protein 5 Regulates the Lysosomal

Calcium Compartment in

T Lymphocytes.

Front. Immunol. 8:94.

doi: 10.3389/fimmu.2017.00094

\section{GTPase of the Immune-Associated Nucleotide Protein 5 Regulates the Lysosomal Calcium Compartment in T Lymphocytes}

\author{
Daniel Serrano', Farnaz Ghobadi', Guylain Boulay ${ }^{2,3}$, Subburaj llangumaran ${ }^{1,3}$, \\ Christine Lavoie $^{2,3}$ and Sheela Ramanathan ${ }^{1,3 *}$ \\ ${ }^{1}$ Immunology Division, Department of Pediatrics, Université de Sherbrooke, Sherbrooke, QC, Canada, ${ }^{2}$ Department of \\ Pharmacology-Physiology, Faculty of Medicine and Health Sciences, Université de Sherbrooke, Sherbrooke, QC, Canada, \\ ${ }^{3}$ Centre de recherche clinique, Université de Sherbrooke, Sherbrooke, QC, Canada
}

T lymphocytes from Gimap5/yp/yp rats carrying a recessive mutation in the GTPase of immune-associated protein 5 (Gimap5) gene undergo spontaneous apoptosis. Molecular mechanisms underlying this survival defect are not yet clear. We have shown that Gimap5 5yplyp T lymphocytes display reduced calcium influx following T cell antigen receptor (TCR) stimulation that was associated with impaired buffering of calcium by mitochondria. Here, we investigated the subcellular localization of GIMAP5 and its influence on $\mathrm{Ca}^{2+}$ response in HEK293T cells and T lymphocytes. The more abundantly expressed GIMAP5v2 localizes to the lysosome and certain endosomal vesicles. Gimap5 5yp/yp T lymphocytes showed increased accumulation of calcium in the lysosomes as evidenced by Gly-Phe $\beta$-naphthylamide (GPN) triggered $\mathrm{Ca}^{2+}$ release. As a corollary, GPN-induced $\mathrm{Ca}^{2+}$ flux was decreased in HEK293T cells expressing GIMAP5V2. Strikingly, TCR stimulation of rat, mouse, and human T lymphocytes increased lysosomal calcium content. Overall, our findings show that lysosomes modulate cellular $\mathrm{Ca}^{2+}$ response during T cell activation and that GIMAP5 regulates the lysosomal $\mathrm{Ca}^{2+}$ compartment in T lymphocytes.

Keywords: GIMAP5, calcium, T cells, lysosomes, lyp mutation

\section{INTRODUCTION}

In $\mathrm{T}$ lymphocytes, calcium influx induced by $\mathrm{T}$ cell antigen receptor (TCR) stimulation modulates up to $75 \%$ of genes implicated in survival and proliferation through activation of calcineurin and NFAT, leading to IL-2 gene expression (1). TCR engagement triggers the activation of LCK and ZAP70 tyrosine kinases, which phosphorylate many substrates including the scaffolding protein Linker for Activation of $\mathrm{T}$ cells, leading to the assembly of a multimolecular signaling platform at the plasma membrane (2). Phospholipase $\mathrm{C} \gamma(\mathrm{PLC} \gamma)$ that is recruited to this complex becomes activated and hydrolyzes the membrane-bound phosphatidylinositol 4,5 bisphosphate $\left(\mathrm{PIP}_{2}\right)$ to generate inositol 1,4,5-trisphosphate $\left(\mathrm{IP}_{3}\right)$ and diacylglycerol (DAG). $\mathrm{IP}_{3}$ binds to its receptor $\mathrm{IP}_{3} \mathrm{R}$ on endoplasmic reticulum (ER) and triggers $\mathrm{Ca}^{2+}$ release from 
the ER store, resulting in a conformational change in the ER-localized STIM1 protein $(3,4)$. This event relays a signal to open the $\mathrm{Ca}^{2+}$ release-activated $\mathrm{Ca}^{2+}$ (CRAC) channel on the plasma membrane, inducing capacitative $\mathrm{Ca}^{2+}$ entry from the extracellular milieu $(5,6)$. CRAC channels are the major store-operated channels (SOC) in T lymphocytes $(7,8)$. TCR stimulation by antigen induces sustained $\mathrm{Ca}^{2+}$ influx via CRAC channels leading to $\mathrm{T}$ cell proliferation (9). Following sustained $\mathrm{Ca}^{2+}$ entry via SOC channels on the plasma membrane, the rising concentration of cytosolic $\mathrm{Ca}^{2+}\left(\left[\mathrm{Ca}^{2+}\right]_{c}\right)$ activates the $\mathrm{Ca}^{2+}$ uniporter on the mitochondrial membrane that induces a slow, membrane potential-driven uptake of $\mathrm{Ca}^{2+}$, which is released later via the $\mathrm{Na}^{+} / \mathrm{Ca}^{2+}$ exchanger (10). This $\mathrm{Ca}^{2+}$ uptake by mitochondria $\left(\left[\mathrm{Ca}^{2+}\right]_{\mathrm{m}}\right)$ is necessary to prevent feedback inhibition of the SOC channel activity by the raising cytosolic $\mathrm{Ca}^{2+}$ concentration $(11,12)$.

In the BB-DP strain of rats, homozygosity for the lyp mutation causes a 5 - to 10 -fold reduction in $\mathrm{CD}^{+} \mathrm{T}$ lymphocyte numbers and absence of $\mathrm{CD}^{+} \mathrm{T}$ lymphocytes in secondary lymphoid organs (13-16). Mature T cells in these rats undergo spontaneous apoptosis soon after they emigrate from the thymus and enter peripheral circulation. The half-life of recently emigrated mature $\mathrm{T}$ cells is markedly reduced in BB-DP rats compared to non-lymphopenic rats ( 3 versus $>15$ days) (16-20). The lyp allele arises from a frameshift mutation within the GTPase domain of the immune-associated nucleotide-binding protein 5 (Gimap5) gene, resulting in a hypothetical protein lacking 223 amino acids at the C-terminus that is not expressed $(21,22)$. GIMAP5 is a member of the GIMAP family that is implicated in immune functions in plants and mammals, and arose by convergent evolution $(23,24)$. In mice, GIMAP5 was shown to interact with members of the Bcl-2 family of antiapoptotic proteins (25-28), whereas another study implicated GIMAP5 in ER stress response (29). In contrast, we have shown that in rat $\mathrm{T}$ cells, endogenous GIMAP5 resides in a cellular compartment distinct from mitochondria and ER and that neither endogenous rat GIMAP5 nor the overexpressed protein interacts with Bcl-2 (30). Yet, loss of GIMAP5 impairs mitochondrial membrane integrity (31). Despite a decade of efforts by several groups, there is a lack of consensus on the mechanisms through which GIMAP5 promotes the survival of quiescent $\mathrm{T}$ lymphocytes.

We have shown previously that signals through TCR and IL-7 receptor that are required for the survival of T lymphocytes in the secondary lymphoid organs (32-36) were reduced in the absence of functional Gimap5 $(37,38)$. Furthermore, we showed that T lymphocytes from Gimap5 $5^{\text {lyp/lyp }}$ rats display defective $\mathrm{Ca}^{2+}$ flux in response to TCR signaling (39). However, the mechanisms by which GIMAP5 regulates cellular $\mathrm{Ca}^{2+}$ homeostasis are not yet clear. We observed that the loss of Gimap5 did not influence $\mathrm{Ca}^{2+}$ release from the ER in primary T lymphocytes (39). On the other hand, GIMAP5 deficiency in T lymphocytes compromised the ability of the mitochondria to sequester $\mathrm{Ca}^{2+}$ that enters via SOC channels (40). Consistent with this, overexpression of GIMAP5 in HEK293T cells resulted in increased $\mathrm{Ca}^{2+}$ accumulation within the mitochondria (40). Given that GIMAP5 is not physically located on the mitochondria (30), how GIMAP5 regulates mitochondrial $\mathrm{Ca}^{2+}$ is not known. Here, we show that GIMAP5 regulates lysosomal $\mathrm{Ca}^{2+}$ and that lysosomes contribute to $\mathrm{Ca}^{2+}$ homeostasis during $\mathrm{T}$ cell activation.

\section{RESULTS}

\section{GIMAP5 Is Localized on Lysosomes and Certain Vesicles through the C-Terminal Anchor}

Rat T lymphocytes express two isoforms of GIMAP5 that differ in the N-terminal avrRpt2-induced gene 1 (AIG) domain, but possess a coiled-coil domain and a transmembrane (TM) domain (Figure 1A). Expression of the shorter variant (GIMAP5v2) is 8 - to 10 -fold higher in comparison to the longer variant (GIMAP5v1) in primary rat $\mathrm{T}$ lymphocytes (Figure 1B, left panel). However, following activation of $\mathrm{T}$ lymphocytes, the expression of both isoforms was reduced by $24 \mathrm{~h}$ (Figure 1B) and corresponds to the previous observation that in vivo antigen stimulation temporarily overcomes the requirement for GIMAP5 (19). The TM domain, which is common to both GIMAP5 variants, targets the protein to certain intracellular membranes. Human and murine GIMAP5 proteins have been reported to be present on lysosomes in T lymphocytes (41). We constructed full-length and TM-deletion constructs of GIMAP5v1 and GIMAP5v2 to evaluate their subcellular distribution and functions (Figure S1 in Supplementary Material). We observed that overexpressed rat GIMAP5 variants colocalized with lysosomal membrane proteins such as LAMP2 and TPC2 (Figure 2), but not with Lysotracker Red that predominantly localizes to the lysosomal lumen (Figure S2 in Supplementary Material). Deletion of TM domain in GIMAP5v2 $\Delta$ TM abolished its lysosomal localization (Figure 2A), suggesting that GIMAP5 is anchored on the lysosomes through the C-terminal TM domain. Accordingly, real-time monitoring of lysosomes in HEK293T or HeLa cells transfected with GIMAP5v2 showed a vesicular pattern of staining; some of these vesicles also stained for LAMP1 and were in constant movement in transfected HEK293T cells (Video S1 in Supplementary Material). In addition to lysosomes, GIMAP5 also colocalized with Rabs 4, 5, 7,9 , and 11, which are markers of early- and late-endocytic and recycling compartments but not with trans-Golgi vesicles (Figure 3).

We have shown previously that overexpressed GIMAP5v2 colocalized with microtubules (40). To determine whether this association resulted from the interaction of lysosomes with microtubules, we expressed cherry- $\alpha$-tubulin in HEK293T cells stably expressing FLAG-tagged GIMAP5 variants. As shown in Figure S4A in Supplementary Material, both variants colocalized with microtubules, with a significantly higher colocalization coefficient for GIMAP5v2. On the other hand, both the variants of GIMAP5 did not colocalize with actin (Figure S3B in Supplementary Material). Deletion of the TM domain resulted in a diffuse cytoplasmic staining and showed increased colocalization with microtubules, probably due to the loss of the restraints posed by the TM anchor. Accordingly, the expression 


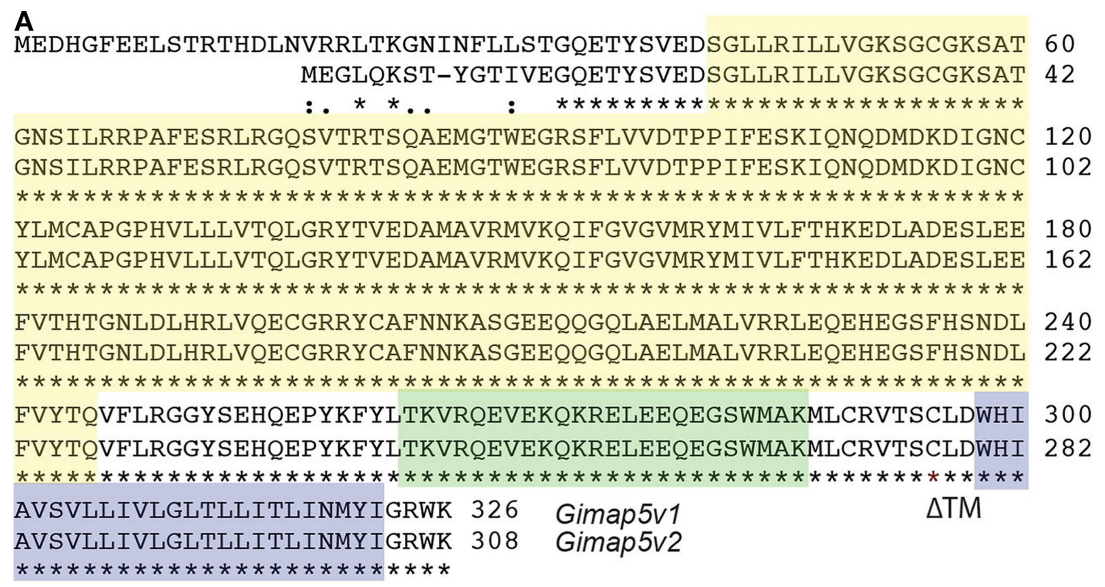

Cytosolic $\square$ Coiled-coil

Trans membrane
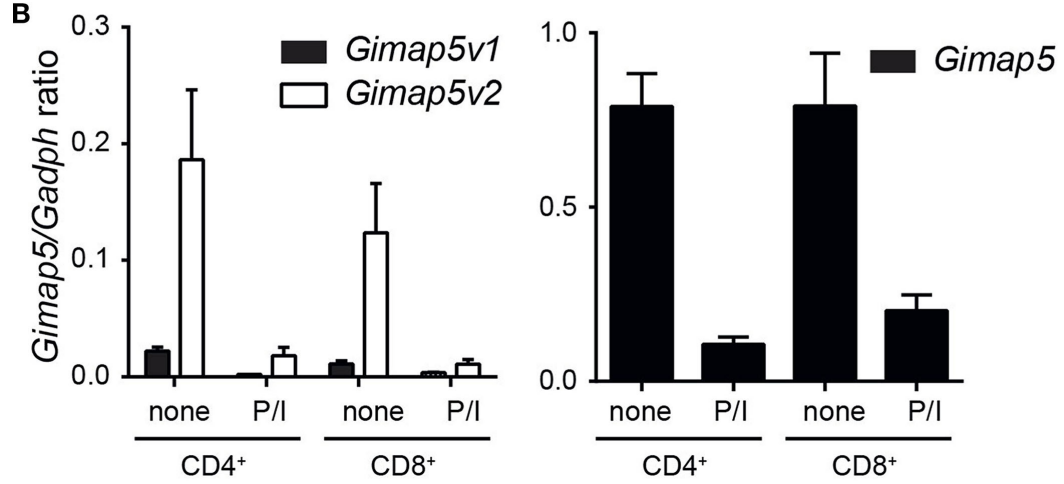

FIGURE 1 | Expression of Gimap5 isoforms in rat T lymphocytes. (A) Sequence alignment of v1 and v2 variants of rat GIMAP5 protein. The cytosolic (yellow), coiled-coil (green) transmembrane (transmembrane; blue) domains are indicated by a box. The predicted structure was obtained from http://www.uniprot.org/ uniprot/Q0R3W7. (B) Gimap5 mRNA expression in primary T lymphocytes was measured by RT-qPCR. CD4+ and CD8 ${ }^{+}$T lymphocytes were purified from lymph nodes of Gimap5 5y/lyp and control rats and stimulated with PMA/ionomycin (P/l) for $24 \mathrm{~h}$. Expression of the Gimap5 isoforms v1 and v2 (left panel) and total Gimap5 (right panel) in control and stimulated lymphocytes was measured by RT-qPCR using specific primers.

of GIMAP5v2 $\Delta$ TM did not show any vesicular pattern of staining when compared to the full-length protein (Video S2 in Supplementary Material).

The above results indicated that GIMAP5 is inserted in the lysosomal and vesicular membranes through the C-terminal anchor and suggested that the N-terminal region of GIMAP5 resides in the cytosol and interacts with microtubules. Distinct motor proteins are involved in the movement of organelles on microtubules $(42,43)$. Because of the possible implication of GIMAP5 in organelle movement, we investigated its colocalization with the molecular motor proteins, kinesin and dynein, that interact with microtubules (42). Significant colocalization of rGIMAP5v2 occurred with kinesin but not with dynein, suggesting that GIMAP5 may be involved in kinesin-mediated retrograde cargo movement (Figures S4 and S5 in Supplementary Material). To visualize the movement of GIMAP5-containing vesicles, HEK293T cells that stably express EGFP-tagged GIMAP5v2 were transfected with cherry-tagged $\alpha$-tubulin and the dynamics of GIMAP5v2containing vesicles was assessed by epifluorescence microscopy.
Microtubule-associated GIMAP5v2-containing vesicles showed directional movement along the microtubules (Figure 4; Video S3 in Supplementary Material).

\section{GIMAP5v2, but Not GIMAP5v1, Regulates Cellular $\mathrm{Ca}^{2+}$}

While the absence of GIMAP5 results in precocious death of $\mathrm{T}$ lymphocytes, its overexpression also induces apoptosis in $\mathrm{T}$ cell lines (29). In addition to apoptosis, T lymphocytes from Gimap $5^{l y p / l y p}$ rats showed diminished $\mathrm{Ca}^{2+}$ influx from the extracellular medium following activation through the $\mathrm{T}$ cell receptor (39). As Gimap5v2 was more abundant than Giamp5v1 in rat T lymphocytes (Figure 1B), it is possible that GIMAP5v2 mediates the regulation of $\mathrm{Ca}^{2+}$ homeostasis. To determine whether Gimap5v1 also regulates cellular $\mathrm{Ca}^{2+}$, we studied the $\mathrm{Ca}^{2+}$ flux in HEK293T cells expressing GIMAP5v1. We have shown previously that expression of GIMAP5v2 in HEK293T cells did not induce apoptosis, but modulates $\mathrm{Ca}^{2+}$ flux in a manner reminiscent of the responses observed in $\mathrm{T}$ lymphocytes $(30,39,40)$. In the absence of extracellular $\mathrm{Ca}^{2+}$, thapsigargin (TG)-induced 

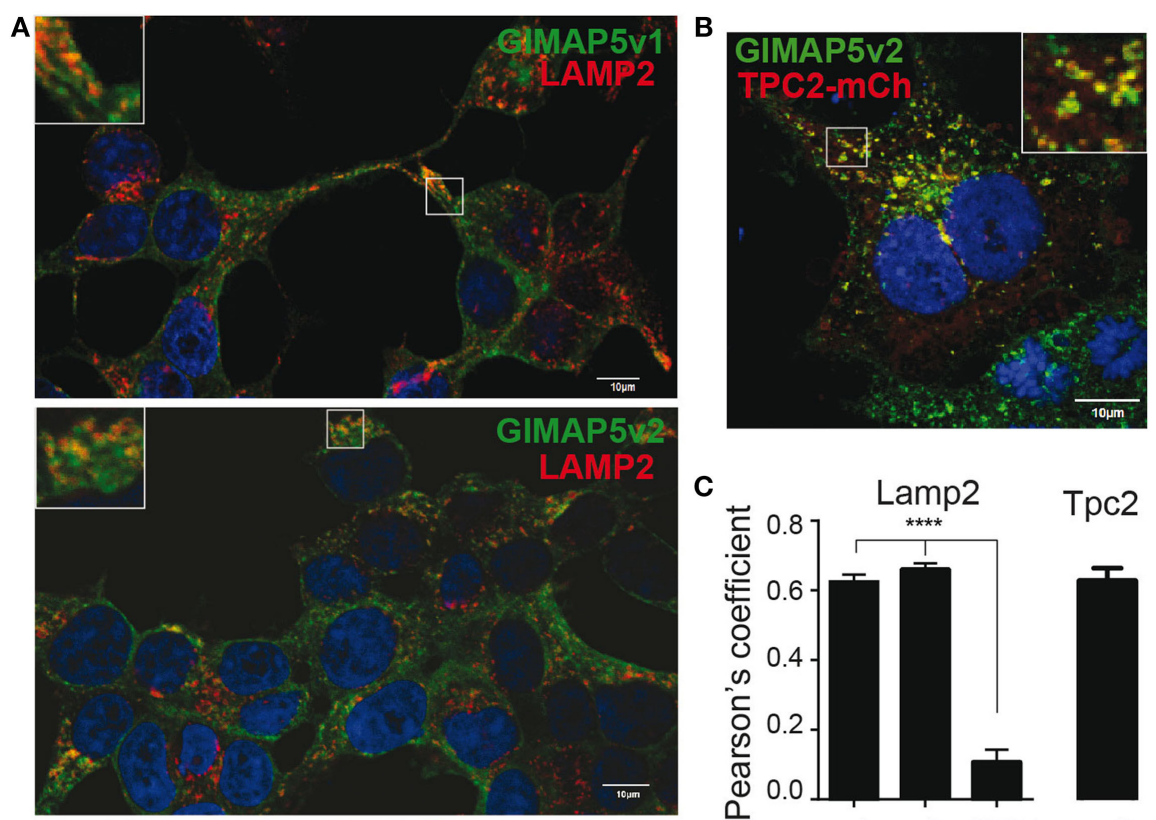

C
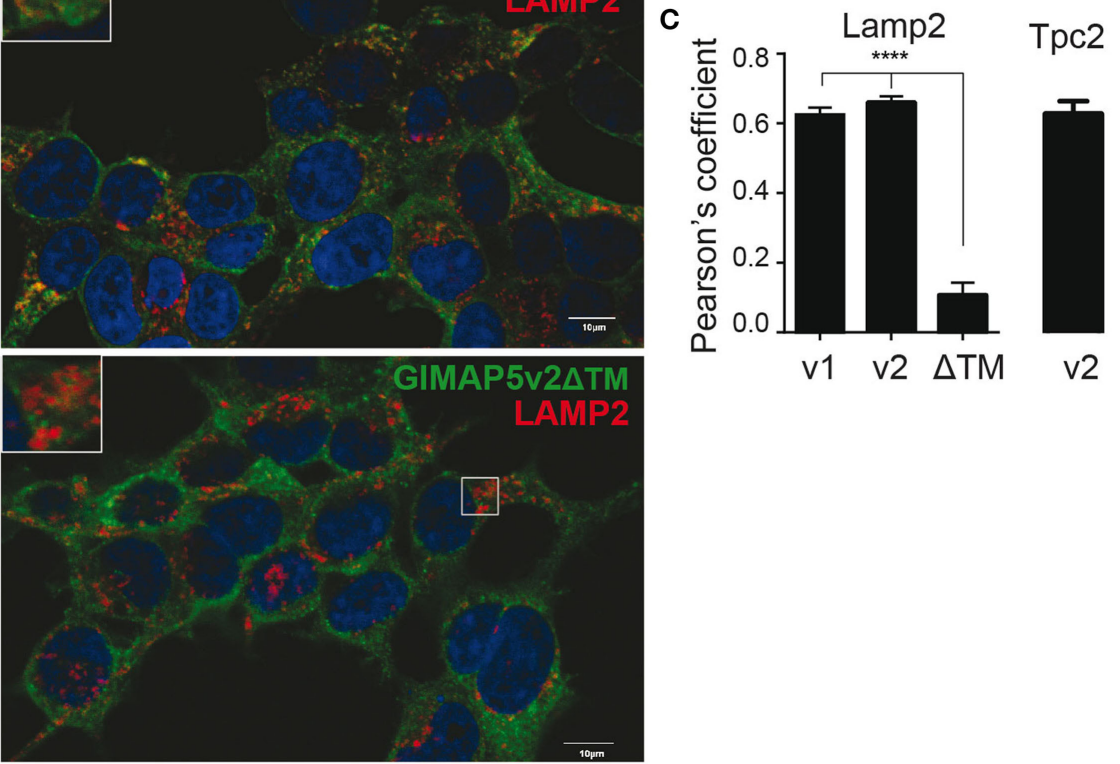

v1 v2 $\triangle T M \quad$ v2

FIGURE 2 | GIMAP5 variants are anchored on the lysosomal membrane through C-terminal transmembrane domain. (A-C) Stable transfectants of HEK293T cells expressing full-length or C-terminal transmembrane domain-deleted GIMAP5 constructs tagged with EGFP were labeled with (A) anti-LAMP2 antibody (B) or cherry-TPC2 and analyzed by confocal microscopy. Bar represents $10 \mu \mathrm{m}$. Insets show the area analyzed for colocalization. (C) Colocalization values are expressed as Pearson's coefficient. Representative data from four experiments with 6-14 cells analyzed per experiment (A) and three experiments with 2-5 cells analyzed per experiment (B) are shown.

release of $\mathrm{Ca}^{2+}$ from the ER was comparable in cells expressing GIMAP5v1, GIMAP5v2, or the $\triangle \mathrm{TM}$ constructs (Figure 5A), suggesting that GIMAP5 does not influence $\mathrm{Ca}^{2+}$ release from the ER store. These observations are also in agreement with our previous report that $\mathrm{Ca}^{2+}$ release from the ER was not affected by the lyp mutation in rat T lymphocytes (39). On the other hand, TG-induced $\mathrm{Ca}^{2+}$ influx in the presence of extracellular $\mathrm{Ca}^{2+}$ was significantly reduced in cells expressing GIMAP5v2 but not in cells expressing GIMAP5v1 or GIMAP5v2 $\Delta$ TM (Figures 5B,C), indicating that the N-terminal domain of GIMAP5v2 and the membrane anchor is required for regulating $\mathrm{Ca}^{2+}$ influx.

\section{GIMAP5v2 Does Not Influence Mitochondrial $\mathrm{Ca}^{2+}$ Content}

Even though $\mathrm{T}$ lymphocytes from Gimap5 $5^{\text {lyp/lyp }}$ rats display impaired mitochondrial $\mathrm{Ca}^{2+}$ uptake, this defect was not observed when the lymphocytes were permeabilized (40), suggesting that the primary defect in cellular $\mathrm{Ca}^{2+}$ homeostasis in these lymphocytes may not be at the level of mitochondria. To determine whether there were differences in the mitochondrial $\mathrm{Ca}^{2+}$ content in resting state, we probed the mitochondrial content by releasing its $\mathrm{Ca}^{2+}$ using Carbonyl cyanide 4-(trifluoromethoxy) phenylhydrazone (FCCP), which uncouples the mitochondrial membrane potential. As shown in Figure 6A, the amount of $\mathrm{Ca}^{2+}$ released from the mitochondria in Gimap5 5 lyp/lyp $\mathrm{T}$ lymphocytes was slightly lower than that observed in Tlymphocytes from control rats. These observations suggest that the mitochondrial $\mathrm{Ca}^{2+}$ content may be reduced in $\mathrm{T}$ lymphocytes due to the lyp mutation. It is also possible that this reduction in the mitochondrial $\mathrm{Ca}^{2+}$ content is a refection of the modest loss in mitochondrial membrane potential ex vivo (30). To determine whether GIMAP5 intrinsically influences the mitochondrial $\mathrm{Ca}^{2+}$ stores directly, we assessed cytosolic $\mathrm{Ca}^{2+}$ released by FCCP in control and GIMAP5v2-expressing HEK293T cells. In the absence of extracellular $\mathrm{Ca}^{2+}$, the release of $\mathrm{Ca}^{2+}$ from mitochondria by FCCP was comparable between control and GIMAP5v2-expressing 


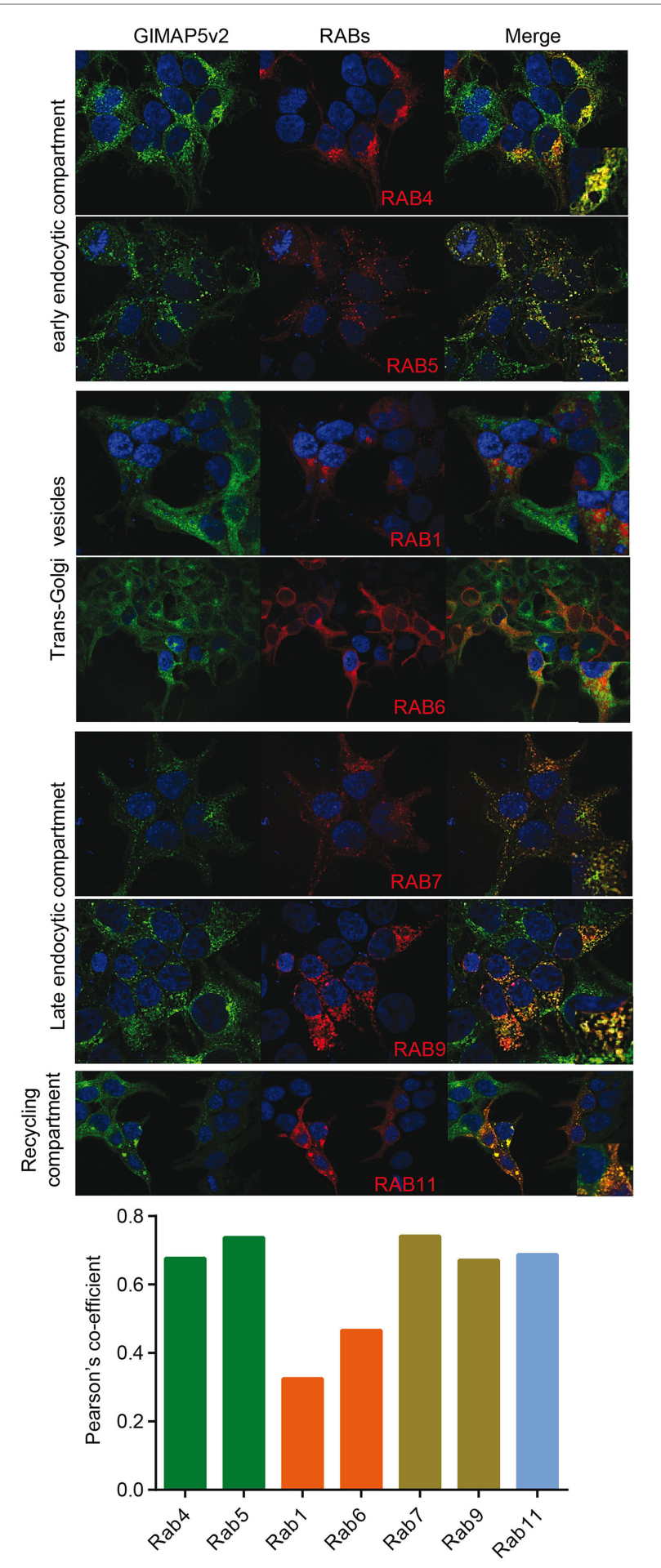

FIGURE 3 | GIMAP5v2 is expressed on certain vesicles. 293T cells expressing EGFP-tagged GIMAP5v2 were transiently transfected with plasmids expressing pmRFP-Rab5, pmRFP-Rab7, pDSRed-Rab9, pDSRed-Rab11, HA-Rab1a, HA-Rab4, or HA-Rab6a. HA-tagged Rabs were labeled with anti-HA antibody followed by secondary anti-mouse antibody tagged with Alexa Fluor 633 and analyzed by confocal microscopy. Colocalization values are expressed as Pearson's coefficient. Representative data from two experiments with four to six cells analyzed per experiment are shown. cells (Figure 6B). These observations suggest that GIMAP5 minimally influences the $\mathrm{Ca}^{2+}$ content of mitochondria at steady state. However, similar to the results obtained with TG, the entry of $\mathrm{Ca}^{2+}$ from extracellular milieu following FCCP was still significantly decreased in HEK293T cells expressing GIMAP5v2 (40). Thus, even if the $\mathrm{Ca}^{2+}$ buffering capacity of mitochondria is higher in GIMAP5v2-expressing $293 \mathrm{~T}$ cells as shown by us previously (40), the differences observed in $\mathrm{Ca}^{2+}$ influx from extracellular medium cannot be explained by alterations in the mitochondrial $\mathrm{Ca}^{2+}$ content in the steady state.

\section{GPN-Induced $\mathrm{Ca}^{2+}$ Release Is Increased in the Absence of GIMAP5v2}

As GIMAP5v2 localizes to the lysosomal membrane (Figure 2), interacts with kinesin (Figure S4 in Supplementary Material), and the GIMAP5v2-containing vesicles (Figure 4) move along the microtubule network, it is possible that GIMAP5v2 might be involved in the regulation of lysosomal $\mathrm{Ca}^{2+}$ homeostasis. We assessed the possibility that GIMAP5 influences lysosomal $\mathrm{Ca}^{2+}$ content. Hydrolysis of Gly-Phe $\beta$-naphthylamide (GPN) within the lysosomes by cathepsin $\mathrm{C}$ results in osmotic lysis of the acidic compartment (44). Thus, GPN-mediated release is a reflection of the $\mathrm{Ca}^{2+}$ content of lysosomes. Treatment with GPN resulted in a higher cytosolic $\mathrm{Ca}^{2+}$ content in $\mathrm{T}$ lymphocytes from Gimap5 $5^{\text {lyp/lyp }}$ rats when compared to T lymphocytes from control rats (Figure 7A). When GPN was added in the presence of extracellular $\mathrm{Ca}^{2+}$, influx from extracellular milieu was observed in $\mathrm{T}$ lymphocytes suggesting that emptying of lysosomal stores can induce $\mathrm{Ca}^{2+}$ influx through the plasma membrane in $\mathrm{T}$ lymphocytes (Figure 7B). In support, acidic stores have been shown to express STIM1 and STIM2 in human platelets (45). Strikingly, Gimap5 $5^{l y p / l y p}$ T lymphocytes, despite showing increased lysosomal $\mathrm{Ca}^{2+}$ release (Figure 7A), displayed substantially reduced $\mathrm{Ca}^{2+}$ influx from the extracellular medium when compared to controls (Figure 7B).

To understand the mechanisms by which GIMAP5 influences lysosomal $\mathrm{Ca}^{2+}$ compartment, we probed the lysosomal $\mathrm{Ca}^{2+}$ content in HEK293T cells stably expressing different constructs of GIMAP5. The GPN-induced $\mathrm{Ca}^{2+}$ release was reduced in cells expressing GIMAP5v2, but not in cells expressing empty vector, GIMAP5v1, or GIMAP5v2 $\Delta \mathrm{TM}$ (Figure 7C). These observations suggest that the presence of full-length GIMAP5v2 is required and is sufficient to prevent the accumulation of $\mathrm{Ca}^{2+}$ by lysosomes. To determine whether the lysosomal and $\mathrm{ER} \mathrm{Ca}^{2+}$ stores are related and to determine whether they influence each other, we sequentially released $\mathrm{Ca}^{2+}$ from lysosomes and $\mathrm{ER}$ (Figure 7C). The release of $\mathrm{Ca}^{2+}$ from the ER after lysosomal release was higher in cells expressing GIMAP5v2. Sequential release of $\mathrm{Ca}^{2+}$ from lysosomes and ER in GIMAP5v2-expressing cells resulted in a greater influx of $\mathrm{Ca}^{2+}$ from the extracellular milieu when compared to that of control cells. As treatment with TG, FCCP (40), or GPN alone (Figure 7D) resulted in reduced $\mathrm{Ca}^{2+}$ influx from extracellular milieu in GIMAP5v2-expressing cells, it suggests that in HEK293T cells, the lysosomal and ER $\mathrm{Ca}^{2+}$ stores may be interconnected (46). Due to the fragility of Gimap5 $5^{\text {lypllyp }} \mathrm{T}$ lymphocytes, we could not carry out similar experiments in primary $\mathrm{T}$ lymphocytes. Nevertheless, our 


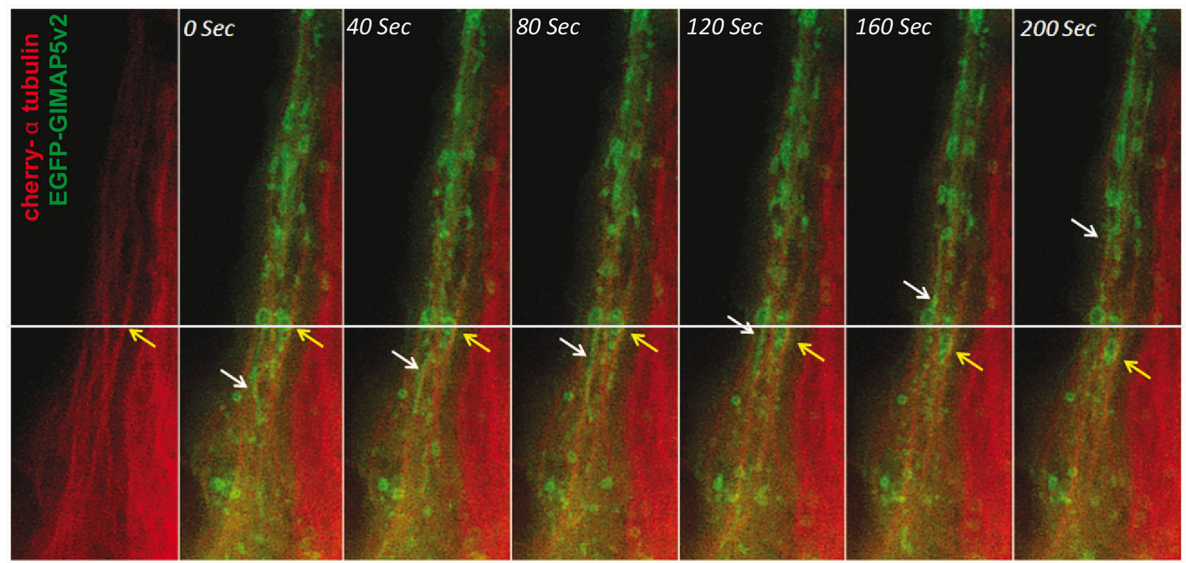

FIGURE 4 | GIMAP5v2-expressing vesicles move along microtubules. HeLa cells were transfected with vectors containing cherry- $\alpha$ tubulin and EGFP-tagged GIMAP5v2. White and yellow arrows track the movement of certain vesicles. The vesicles are either filamentous or spherical. The speed of their movement is not uniform. Bar represents $10 \mu \mathrm{m}$. Frames were taken from Video S3 in Supplementary Material.
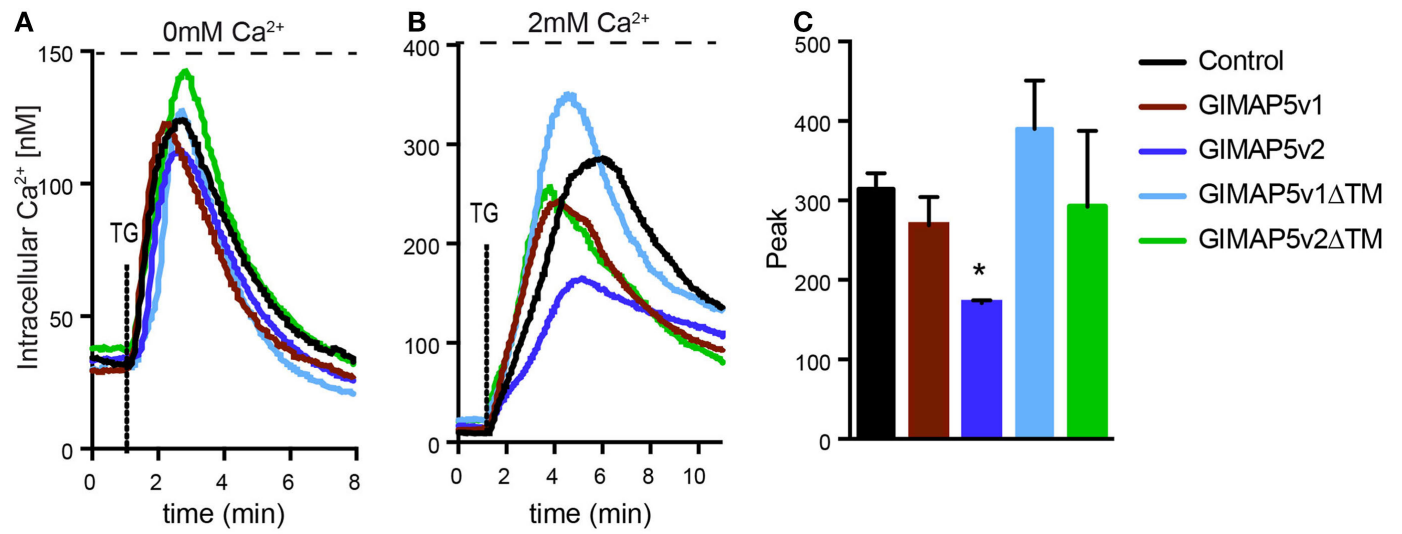

FIGURE 5 | Full-length GIMAP5v2 regulates intracellular $\mathrm{Ca}^{2+}$ homeostasis. Cytosolic $\mathrm{Ca}^{2+}$ concentration following the addition of TG was measured using Fura-2 in HEK293T stable cell lines expressing empty vector or different GIMAP5 constructs following the addition of TG. (A) Ca ${ }^{2+}$ release from the endoplasmic reticulum (ER) was measured in medium containing $0 \mathrm{mM} \mathrm{Ca}^{2+}$ and $0.5 \mathrm{mM}$ EGTA following addition of TG. (B) Increase in cytosolic Ca ${ }^{2+}$ induced by release of the ER store and influx from the extracellular medium was measured following the addition of TG in the presence of $2 \mathrm{mM} \mathrm{Ca}^{2+}$. For all experiments, cells were plated on cover slips $48 \mathrm{~h}$ before analysis. Each experiment is an average of 40-60 cells. Representative data from three to five independent experiments with comparable results are shown. (C) Peak value for cytosolic $\mathrm{Ca}^{2+}$ influx shown in (B) is plotted as a bar graph and compared by Student's $t$-test $\left({ }^{*} p<0.05\right)$.
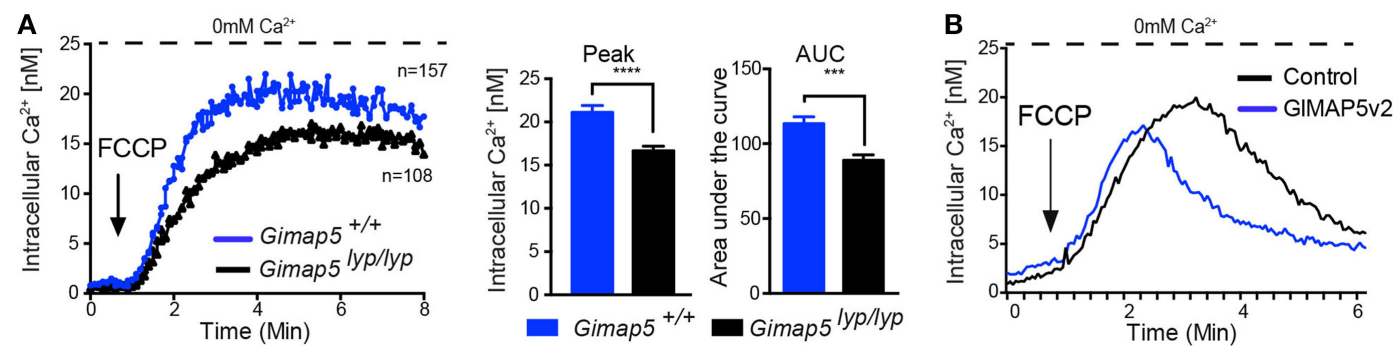

FIGURE 6 | Influence of GIMAP5v2 on Ca ${ }^{2+}$ release from mitochondria. Cytosolic $\mathrm{Ca}^{2+}$ concentration following the addition of $\mathrm{FCCP}(50 \mu \mathrm{M})$ was measured in the absence of extracellular $\mathrm{Ca}^{2+}$ in Fura-2-loaded (A) CD4+ T lymphocytes purified from Gimap5 $5 \mathrm{pph} / \mathrm{yp}$ and control rats and in (B) Fura-2-loaded HEK293T stable cell lines expressing empty vector or GIMAP5v2. For all experiments, cells were plated on cover slips $48 \mathrm{~h}$ before analysis. Each experiment is an average of 40-60 cells. Representative data from two independent experiments are shown. Peak value for cytosolic $\mathrm{Ca}^{2+}$ influx for primary $\mathrm{T}$ lymphocytes is plotted as a bar graph and compared by Student's $t$-test $\left({ }^{*} p<0.05\right)$. 
A
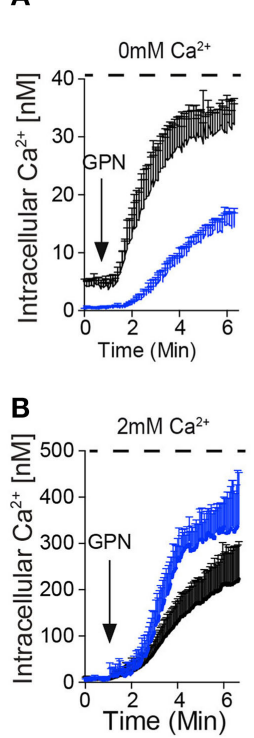

E

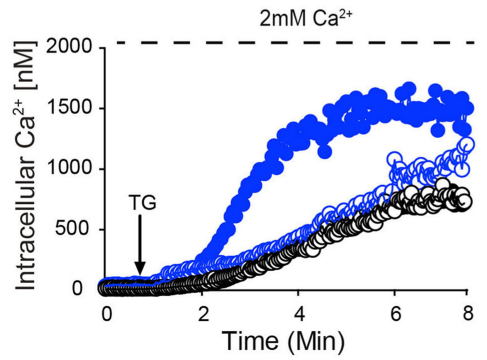

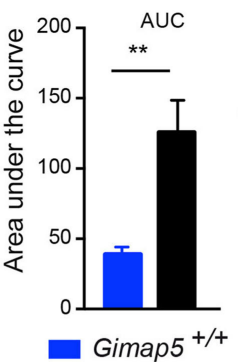

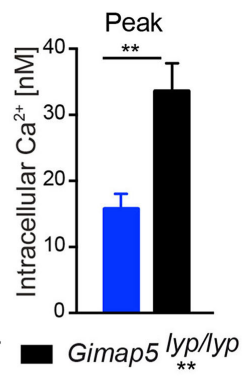

AUC
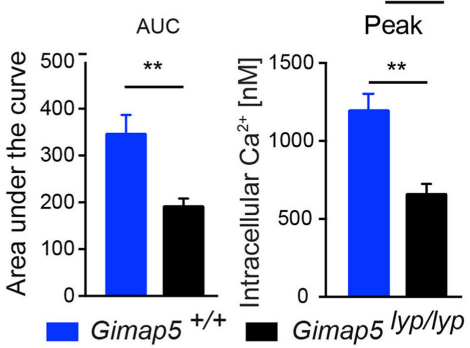

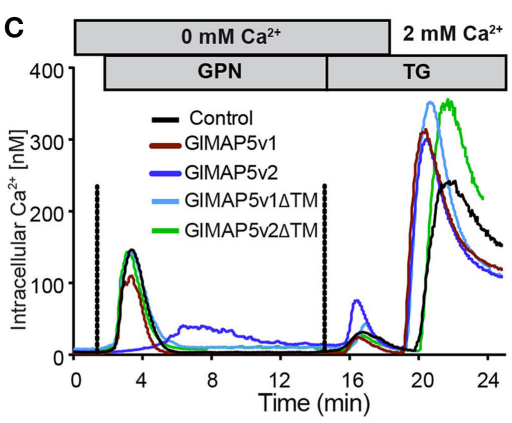

D

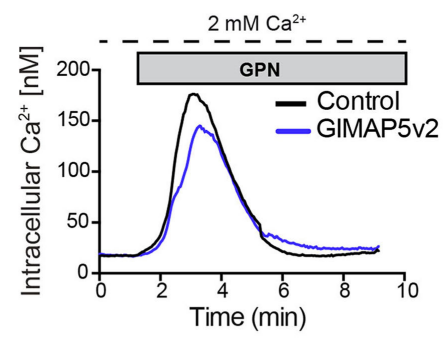

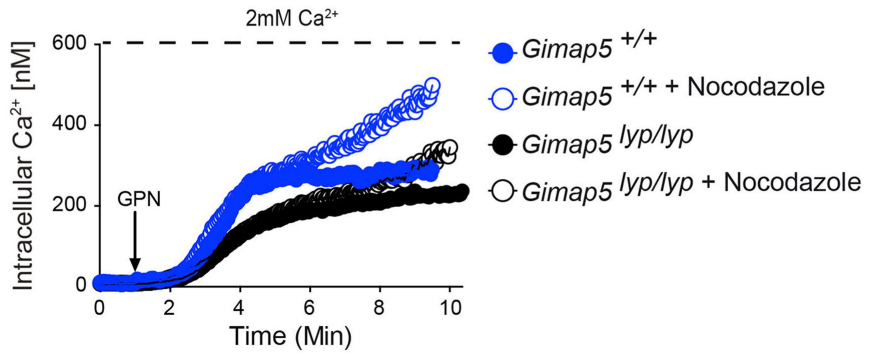

FIGURE 7 | GPN-mediated release of $\mathbf{C a}^{2+}$ is increased in the absence of GIMAP5. Peripheral CD4+ $\mathrm{T}$ lymphocytes purified from Gimap5 $5^{\mathrm{yp} / \mathrm{yp}}$ and control rats were loaded with Fura-2 and intracellular $\mathrm{Ca}^{2+}$ was measured as described. The arrow indicates the time of addition of GPN (100 $\left.\mu \mathrm{M}\right)$. Cytosolic Ca ${ }^{2+}$ was measured following addition of GPN in the absence (A) or presence (B) of extracellular $\mathrm{Ca}^{2+}$. The histograms represent the area under curve (AUC) and the peak values. Student's $t$-test $\left({ }^{* *} p<0.005\right)$. (C) Cytosolic $\mathrm{Ca}^{2+}$ was measured using Fura-2-labeled stable transfectants of the indicated GIMAP5 constructs. The cells were maintained in $\mathrm{Ca}^{2+}$-free medium $\left(0 \mathrm{mM} \mathrm{Ca}{ }^{2+}\right.$ and $\left.0.5 \mathrm{mM} \mathrm{EGTA}\right)$, and $\mathrm{GPN}$ and TG were added sequentially as indicated before adding $\mathrm{Ca}^{2+}$ to the extracellular medium. (D) $\mathrm{Ca}^{2+}$ release from stable transfectants of the vector control or GIMAP5v2 following addition of GPN in the presence of extracellular $\mathrm{Ca}^{2+}$. (E) Cytosolic $\mathrm{Ca}^{2+}$ was measured following addition of TG or GPN in the presence of extracellular $\mathrm{Ca}^{2+}$ in T lymphocytes pretreated or not with nocodazole $(2 \mu \mathrm{M})$ for $30 \mathrm{~min}$.

findings on the overexpression system lend support to the idea that dynamic interaction between lysosomes and ER modulates the $\mathrm{Ca}^{2+}$ flux response (47).

\section{Nocodazole Treatment Increases the $\mathrm{Ca}^{2+}$ Influx Following GPN Treatment}

Mitochondrial movement on cytoskeletal elements to $\mathrm{Ca}^{2+}$-rich microdomains is required for the maintenance of the steady influx of the $\mathrm{Ca}^{2+}(12,40,48)$. In $\mathrm{T}$ lymphocytes, soluble mediators such as anti-TCR antibodies or TG requires the movement of mitochondria on microtubules while movement on actin filaments is observed to maintain the $\mathrm{Ca}^{2+}$ influx at the immunological synapse $(40,48)$. Even though the capacity of mitochondria to take up $\mathrm{Ca}^{2+}$ is not defective in permeabilized Gimap5 $5^{\text {lyp/lyp }} \mathrm{T}$ lymphocytes, they were not efficient in buffering the $\mathrm{Ca}^{2+}$ influx (40). In support, nocodazole treatment of $\mathrm{T}$ lymphocytes from control rats resulted in a substantial decrease in TG-induced $\mathrm{Ca}^{2+}$ influx through the plasma membrane while minimal effect was observed in T lymphocytes from Gimap $5^{l y p / l y p}$ rats (Figure 7E, left panel). TG-induced $\mathrm{Ca}^{2+}$ influx was decreased as early as $2 \mathrm{~min}$ in control $\mathrm{T}$ lymphocytes, while no difference was observed in Gimap5 $5^{l y p / l y p} \mathrm{~T}$ lymphocytes (Figure 7E, left panel). These observations complement our previous report that addition of nocodazole prevented mitochondrial $\mathrm{Ca}^{2+}$ uptake in $\mathrm{T}$ lymphocytes from controls, but not in Gimap5 5 pp/lyp $\mathrm{T}$ lymphocytes (40). Next we measured $\mathrm{Ca}^{2+}$ influx through the plasma membrane following GPN treatment in Tlymphocytes that were pretreated with nocodazole. To our surprise, we observed that the lysis of lysosomes and the consequent release of lysosomal $\mathrm{Ca}^{2+}$ did not influence $\mathrm{Ca}^{2+}$ influx from the extracellular milieu in both control and Gimap5 $5^{l y p / l y p} \mathrm{~T}$ lymphocytes until 6 min (Figure 7E, right panel). At later time points, the $\mathrm{Ca}^{2+}$ influx was considerably increased in control T lymphocytes, while the mutant $\mathrm{T}$ lymphocytes showed a modest increase. These observations suggest that $\mathrm{Ca}^{2+}$ uptake by 
A

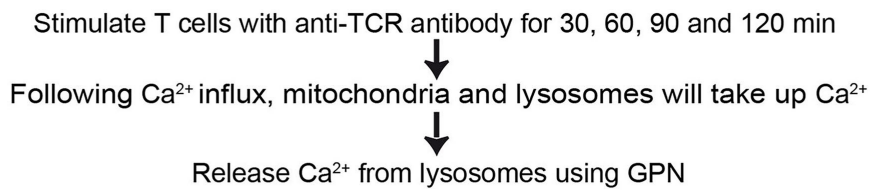

B Rats

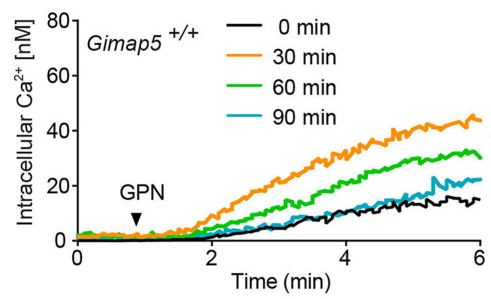

D

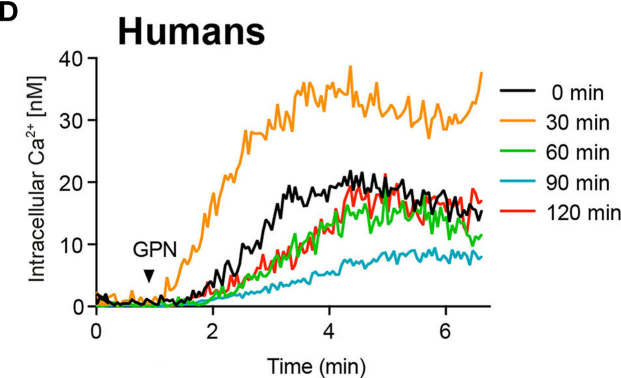

$\mathbf{F}$

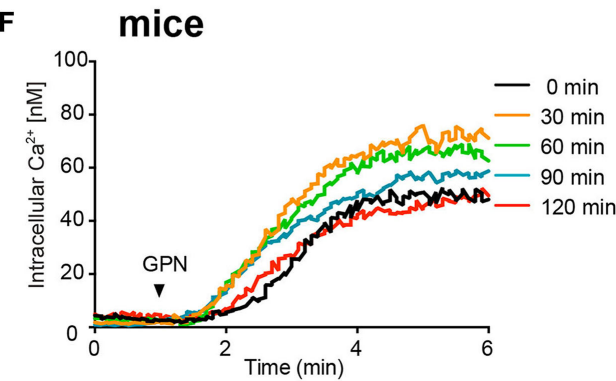

C

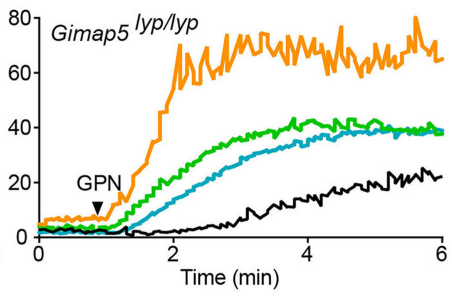

E

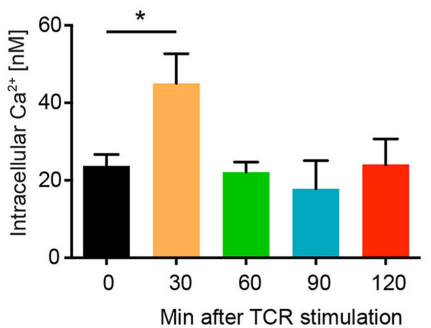

G

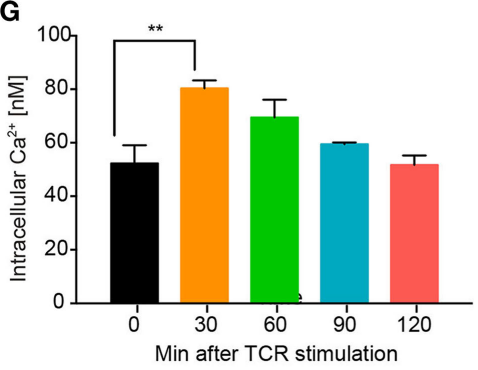

FIGURE 8 | Lysosomes accumulate $\mathbf{C a}^{2+}$ following activation through $\mathbf{T}$ cell receptor. (A) Schematic representation of the experimental setup is indicated. Purified CD4+ T lymphocytes from (B,C) rats, (D,E) humans, and (F,G) mice were plated on coverslips and stimulated with anti-TCR antibody $(\mathrm{R} 73$ for rats, IP26 for humans, and $\mathrm{H} 57$ for mice) for the indicated duration. The lymphocytes were then loaded with Fura-2. Lysosomal Ca ${ }^{2+}$ content was probed with GPN in the absence of extracellular $\mathrm{Ca}^{2+}$. Representative data from one experiment are shown in (B,D,F). The average of peak values from three independent experiments is shown in (C,E,G). ${ }^{9} p<0.05$ between WT and Gimap5 $5^{\text {lyp/lyp }}$ unstimulated ( ${ }^{\star} p<0.05 ;{ }^{* *} p<0.01$ ).

lysosomes, rather than mitochondrial translocation to $\mathrm{Ca}^{2+}$-rich microdomains acts as a brake on sustained $\mathrm{Ca}^{2+}$ influx through the plasma membrane and that GIMAP5 may have a role to play in this regulation.

\section{Lysosomes Accumulate $\mathrm{Ca}^{2+}$ Following Crosslinking of TCR}

Given that GIMAP5 appears to regulate lysosomal $\mathrm{Ca}^{2+}$ in $\mathrm{T}$ lymphocytes, we assessed the involvement of lysosomes in $\mathrm{Ca}^{2+}$ homeostasis during $\mathrm{T}$ cell activation. Steady influx of $\mathrm{Ca}^{2+}$ through the CRAC channel is maintained by the buffering of cytosolic $\mathrm{Ca}^{2+}$ by mitochondria (11). Mitochondrial $\mathrm{Ca}^{2+}$ increases within 10-15 min following crosslinking of TCR on the cell surface $(40,48)$. To determine whether lysosomes contributed to the accumulation of $\mathrm{Ca}^{2+}$ following $\mathrm{T}$ cell activation, we assessed the lysosomal $\mathrm{Ca}^{2+}$ content at various time points following TCR stimulation by releasing their $\mathrm{Ca}^{2+}$ with GPN. CD4 ${ }^{+}$ T lymphocytes from control and Gimap $5^{\text {lyp/lyp }}$ rats were stimulated with anti-TCR antibody R73 in the presence of $\mathrm{Ca}^{2+}$. At indicated time points, coverslips containing activated $\mathrm{T}$ lymphocytes were transferred to $\mathrm{Ca}^{2+}$-free medium and GPN was added to measure the amount of $\mathrm{Ca}^{2+}$ released from the lysosomes (Figure 8A). The lysosomal $\mathrm{Ca}^{2+}$ content was consistently higher between 30 and 120 min following crosslinking of TCR in T lymphocytes 
from control and Gimap5 $5^{l y p / l y p}$ rats (Figures $\mathbf{8 B}-\mathbf{C}$ ) suggesting that lysosomal $\mathrm{Ca}^{2+}$ accumulation may be a late event following TCR activation. Strikingly, Gimap $5^{\text {lyp/lyp }} \mathrm{T}$ lymphocytes showed increased TCR-induced lysosomal $\mathrm{Ca}^{2+}$ accumulation than control lymphocytes. To determine whether lysosomal $\mathrm{Ca}^{2+}$ accumulation following TCR stimulation is a general phenomenon, we carried out similar experiments on human and murine $\mathrm{CD}^{+} \mathrm{T}$ lymphocytes. In these lymphocytes, increase in lysosomal $\mathrm{Ca}^{2+}$ content occurred at $30 \mathrm{~min}$ after TCR stimulation (Figures 8D-G). These observations suggest that (i) lysosomal $\mathrm{Ca}^{2+}$ accumulation is a late event during $\mathrm{T}$ cell activation and (ii) GIMAP5 prevents lysosomal $\mathrm{Ca}^{2+}$ accumulation in the absence of TCR activation.

\section{DISCUSSION}

The data presented here establish a role for GIMAP5 in regulating $\mathrm{Ca}^{2+}$ homeostasis by modulating lysosomal $\mathrm{Ca}^{2+}$ stores. Lysosomes store significant amounts of $\mathrm{Ca}^{2+}$ and contribute to vesicular trafficking, autophagy, endocytosis, and exocytosis in most of the cell types, including immune cells (49). Exocytosis of cytolytic granules in activated cytotoxic T lymphocytes can be triggered by NAADP and/or ADPR, ligands of TPC and TRPM channels present on lysosomes (50). Our findings have revealed a hitherto unknown function for lysosomal $\mathrm{Ca}^{2+}$ in $\mathrm{T}$ lymphocyte survival and activation and a role for Gimap5 in regulating this process.

Of the two alternate GIMAP5 transcripts expressed in rat $\mathrm{T}$ lymphocytes, the shorter rGIMAP5v2 influences $\mathrm{Ca}^{2+}$ homeostasis in a significant manner, while the longer variant had minimal influence on the cellular $\mathrm{Ca}^{2+}$ responses. As the two transcripts differ at the N-terminal 32 amino acids, it is likely that the domain structure of rGIMAP5v2 plays an important role in regulating $\mathrm{Ca}^{2+}$ homeostasis. This notion is further supported by the higher expression of Gimap $5 v 2$ compared to Gimap5v1 in $\mathrm{T}$ lymphocytes. In accordance with our previous observation that T cell activation transiently rescues Gimap5-deficient T lymphocytes from death, Gimap5 expression is downregulated following T cell activation (19). Two variants of GIMAP5 can be generated in rats and in humans $(26,51)$, whereas only the GIMAP5v2 is expressed in mice (25). On the other hand, mice possess a functional Gimap3, which is a pseudogene in rats and humans (22). One study has shown that loss of Gimap5 and Gimap3 is required for the lymphopenic phenotype in mice (52). These findings raise the possibility that Gimap5v1 in rats and humans, and Gimap3 in mice may complement or regulate the functions of Gimap5v2. Additionally, or alternatively, these GIMAP proteins may form homo- and heterodimers, adding an additional level of complexity to GIMAP5 activity (53).

Our observations confirm and extend the previous report on the lysosomal localization of GIMAP5 (41). GIMAP5 is anchored to the cytosolic side of the lysosomal and vesicular membranes through the C-terminal TM domain, facilitating the cytosolic N-terminal domain to mediate its functions. Even though GIMAP5 is present on endocytic and recycling vesicles that are involved in TCR signaling (54-57), it is not clear at present whether GIMAP5 is implicated in these functions. It is possible that the reduced intensity of tyrosine phosphorylation following activation of Gimap5 mutant T lymphocytes (37, $38,40)$ may be a consequence of defects in specific endosomal compartments. It is also possible that GIMAP5 may have a role in autophagy as GIMAP6, another member of the GIMAP family, has been shown to interact with GABARAPL2, an Atg8 homolog (58).

Current knowledge on the role of lysosomal $\mathrm{Ca}^{2+}$ in $\mathrm{T}$ cell homeostasis is very limited. Lysosomal $\mathrm{Ca}^{2+}$ is implicated in the release of cytotoxic granules (50). Lysosomal storage disorders are associated with immune dysfunctions as a consequence of abnormal accumulation of metabolites (59). However, it is not clear whether $\mathrm{Ca}^{2+}$ homeostasis is also affected in $\mathrm{T}$ lymphocytes from these patients. Similarly, while mitochondrial dysfunction affects lysosomal activity and autophagy in T lymphocytes, their effects on lysosomal $\mathrm{Ca}^{2+}$ have not been studied (60). It is quite probable that deregulation of lysosomal functions are also associated with altered lysosomal $\mathrm{Ca}^{2+}$ content. The data presented here suggest that the lysosomal $\mathrm{Ca}^{2+}$ content of resting $\mathrm{T}$ lymphocytes is maintained at a low level in the presence of GIMAP5 and that it increases during later stages of $\mathrm{T}$ cell activation. $\mathrm{IP}_{3}$ generated following TCR stimulation empties the $\mathrm{ER} \mathrm{Ca}^{2+}$ stores and opens the ORAI/CRAC channels on the plasma membrane (7). The incoming $\mathrm{Ca}^{2+}$ is buffered by mitochondria that move on microtubules (61). Mitochondria buffer the $\mathrm{Ca}^{2+}$ influx during the first 15 min following the opening of CRAC channels induced by the emptying of the $\mathrm{ER} \mathrm{Ca}^{2+}(40,62)$. Our observations with lysosomes add additional regulatory steps to this process. The data presented here show for the first time that lysosomal $\mathrm{Ca}^{2+}$ content peaks around $30 \mathrm{~min}$ following TCR stimulation in rats, mice, and humans (Figure 8). However, we do not rule out the possibility that lysosomes accumulate $\mathrm{Ca}^{2+}$ at the same time or immediately after mitochondria. Inhibition of microtubule polymerization prevents mitochondrial movement for $\mathrm{Ca}^{2+}$ accumulation and hence the $\mathrm{Ca}^{2+}$ influx from the extracellular milieu $(12,40,48)$. However, this inhibition of microtubule polymerization does not seem to affect $\mathrm{Ca}^{2+}$ influx following GPN-mediated lysis of lysosomes but in fact increases the influx, lends credence to the concept that lysosomes play an important role in regulating $\mathrm{Ca}^{2+}$ influx. This increased influx despite the inability of mitochondria to move and buffer this influx suggests that in addition to mitochondria, lysosomal GIMAP5 may be an additional break for the $\mathrm{Ca}^{2+}$ influx in $\mathrm{T}$ lymphocytes. Thus, lysis of lysosomes removes the restraint imposed by GIMAP5 and/or lysosomal $\mathrm{Ca}^{2+}$ and permits increased entry. It is possible that both GIMAP5-mediated restraint (by interacting with cellular components) and lysosomal $\mathrm{Ca}^{2+}$ are important as $\mathrm{Ca}^{2+}$ influx following GPN and TG addition was higher in HEK293T cells expressing the GIMAP5 $\triangle \mathrm{TM}$ as well as in cells expressing GIMAP5v1 (Figure 7C). Comparison of $\mathrm{Ca}^{2+}$ influx observed in Figures 5B and 7C suggests that active ER-lysosomal cross-talk (47) can add additional level of complexity to these interactions (discussed below). It is possible that interaction of GIMAP5 with microtubules prevents the transfer of $\mathrm{Ca}^{2+}$ from lysosomes to the ER during ligand-induced $\mathrm{ER} \mathrm{Ca}^{2+}$ depletion in order to facilitate STIM-ORAI interactions. $\mathrm{Ca}^{2+}$ transfer from the lysosome to the ER contributes to the replenishing of the $\mathrm{ER} \mathrm{Ca}^{2+}$ content $(63,64)$. 
Preventing this transfer will increase the depletion of the ER $\mathrm{Ca}^{2+}$ concentration, and therefore, increasing the $\mathrm{Ca}^{2+}$ influx through the STIM-Orai interaction.

Comparable observations in primary $\mathrm{T}$ lymphocytes and in 293T cells overexpressing GIMAP5 suggest that GIMAP5mediated regulation of cellular $\mathrm{Ca}^{2+}$ homeostasis involves ubiquitously expressed proteins and processes. It is intriguing that in T lymphocytes, this regulation is linked to cell survival, while cell survival is not affected in 293T, Rat2, or HeLa cells (30). Additional experiments in T lymphocytes and different cell types combined with development of techniques to study lysosomal $\mathrm{Ca}^{2+}$ content will be required to understand the contribution of GIMAP5 and lysosomal $\mathrm{Ca}^{2+}$ to the cellular $\mathrm{Ca}^{2+}$ homeostasis.

The regulation of cellular $\mathrm{Ca}^{2+}$ homeostasis by GIMAP 5 may be an indirect effect as GIMAP5 does not possess any known $\mathrm{Ca}^{2+}$-binding EF-motifs and does not form a $\mathrm{Ca}^{2+}$ channel by itself. As GIMAP5 regulates $\mathrm{Ca}^{2+}$ responses in HEK293T cells in a manner reminiscent of primary $\mathrm{T}$ lymphocytes, it is possible that GIMAP5 interacts with ubiquitously expressed proteins that regulate $\mathrm{Ca}^{2+}$ responses in many cell types. Both endogenous and overexpressed GIMAP5v2 regulate cellular $\mathrm{Ca}^{2+}$ in a comparable manner, even though the prosurvival function of GIMAP5v2 is restricted to T lymphocytes (30). The presence of GIMAP5v2 increases mitochondrial $\mathrm{Ca}^{2+}$ uptake in control $\mathrm{T}$ lymphocytes and HEK293T cells expressing GIMAP5v2 (40), without affecting the basal $\mathrm{Ca}^{2+}$ content of mitochondria (Figure 6). However, there are certain subtle differences between primary T lymphocytes and HEK293T cells expressing or not GIMAP5v2. In T lymphocytes, disruption of microtubules, but not actin, influenced TG-induced mitochondrial $\mathrm{Ca}^{2+}$ uptake, while in HEK293T cells both actin and microtubules appear to be involved (40). Exogenous GIMAP5v2 diminished lysosomal $\mathrm{Ca}^{2+}$ stores in HEK293T cells, possibly as a consequence of ER-lysosomal cross-talk (47). However, in contrast to primary $\mathrm{T}$ lymphocytes, the influx of $\mathrm{Ca}^{2+}$ from the extracellular milieu was still decreased in HEK293T cells expressing GIMAP5v2, but was increased following sequential release from lysosomes and ER (Figure 7C). It is possible that the inability of lysosomes to take up $\mathrm{Ca}^{2+}$ in the presence of GIMAP5 disrupts the cross-talk between $\mathrm{Ca}^{2+}$ storage organelles, making it difficult for cells to counter balance premature closure by negative feedback of CRAC channels. While the absence of TM domains that anchors GIMAP5v2 to the lysosomal membrane did not affect $\mathrm{Ca}^{2+}$ responses of HEK293T cells expressing GIMAP5v2 $\Delta$ TM, T cells from Gimap5 $5^{\text {lyplyp }}$ rats show decreased $\mathrm{Ca}^{2+}$ influx and mitochondrial buffering $(39,40)$. These observations highlight the relative importance of the various $\mathrm{Ca}^{2+}$ stores in different cell types. Despite such differences, HEK293T cells were instrumental in characterizing the association of GIMAP5 with lysosomes and to the microtubule network.

Our results also reveal the complex nature of the interaction between the various subcellular $\mathrm{Ca}^{2+}$ stores that are present in a cell, and a role for GIMAP5 in regulating their function in a cell type-specific manner. The $\mathrm{Ca}^{2+}$ released from the ER is taken up by ER-associated mitochondria (65). Lysosomes are also found in close association with ER and NAADP-released $\mathrm{Ca}^{2+}$ can propagate to the ER and trigger a larger $\mathrm{Ca}^{2+}$ release (66). Similarly, bidirectional $\mathrm{Ca}^{2+}$ exchange has been shown between ER and lysosomes (67). In yeast, vCLAMP (vacuole and mitochondria patch) are enriched in ions and regulate transport between lysosomes and mitochondria (68). While the presence of lysosomal $\mathrm{Ca}^{2+}$ appears to be normal in the physiology of non-T cells as evident from the experiments with HEK293T cells, it is not clear why lysosomal $\mathrm{Ca}^{2+}$ is maintained at low levels in T lymphocytes by GIMAP5. It is possible that this reflects the requirement for adequate $\mathrm{Ca}^{2+}$ delivery to mitochondria to maintain the energy requirement in $\mathrm{T}$ lymphocytes during the initial activation phase. Even though we have observed downregulation of Gimap5 gene expression following activation, the half-life of the endogenous GIMAP5 protein in T lymphocytes is not known. It is possible that GIMAP5 protein downregulation is also associated with activation and proliferation of $\mathrm{T}$ lymphocytes. Thus, turning down the expression of GIMAP5 in activated lymphocytes may permit cell cycle progression (69). Clearly, further studies are needed to elucidate the mechanisms by which GIMAP5 regulate the lysosomal calcium store, and why filling up this store in resting GIMAP5-deficient T lymphocytes compromises survival.

\section{MATERIALS AND METHODS}

\section{Animals}

Gimap5 $5^{\text {lypllyp }}$ rats and Gimap5 $5^{+/+}$in the ACI.1u background have been described before (30). C57Bl/6 mice were purchased from Charles River (Sherbrooke, QC, Canada). Rats and mice were housed in micro-isolated sterile cages under specific pathogenfree conditions. This study was carried out in accordance with the recommendations of CCPA guidelines. The protocol was approved by the Institutional Université de Sherbrooke, Faculty of Medicine and Health Sciences Animal Ethical Committee. The protocol number is $050-13 \mathrm{~B}$.

\section{Reagents}

Tissue culture media, fetal calf serum, $\mathrm{CaCl}_{2}$, thapsigargin, anti-FLAG M2 Affinity Gel, and antibodies against $\alpha$-tubulin, Myc and FLAG, and Carbonyl cyanide 4-(trifluoromethoxy) phenylhydrazone (FCCP) were from Sigma-Aldrich (Oakville, ON, Canada). Gly-Phe- $\beta$-naphthylamide (GPN) was obtained from Santa Cruz Biotechnology (Dallas, TX, USA). Nocodazole was obtained from Calbiochem. R73 (anti-rat TCR), H57 (anti-mouse TCR), and IP36 (anti-human TCR) monoclonal antibodies were obtained from Affymatrix-eBiosciences (San Diego, CA, USA). Dynalbeads ${ }^{\circledR}-$ M450 tocylactivated beads, Lysotracker Red, and Fura-2 were from Molecular Probes (Life Technologies, Carlsbad, CA, USA). Anti-LAMP2 (H4B4) $\mathrm{mAb}$ was obtained from Developmental Studies Hybridoma Bank at the University of Iowa (Iowa, IA, USA). Secondary antibodies for immunoblotting were purchased from Jackson ImmunoResearch Laboratories. Secondary antibodies for fluorescence microscopy were purchased from Thermo Fisher Scientific (Waltham, MA, USA).

Plasmids pmEGFP_ $\alpha \_t u b u l i n \_I R E S \_p u r o 2 b$ (Addgene plas-

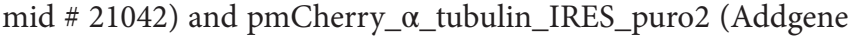


plasmid \# 21043) were kind gifts of Dr. Daniel Gerlich (70). EGFP-IC2-FL (Addgene plasmid \# 51409) was a gift from Dr. Trina Schroer (71). LAMP1-mRFP-FLAG (Addgene plasmid \# 34611) was a gift from David Sabatini (72). EYFP-KIF5C was a gift from Dr. Anne Stephenson (University of London, London, UK) (73). HA-Rabla, HA-Rab4, and HA-Rab6a were kind gifts of Dr. Jean-Luc Parent (Université de Sherbrooke) (74). pmRFPRab5, pmRFP-Rab7, pDSRed-Rab9, and pDSRed-Rab11 have been already described (75).

\section{Plasmid Constructs and Cell Lines}

Full-length or transmembrane-deleted GIMAP5v2 constructs tagged with an N-terminal Flag-tag, or EGFP tag were subcloned from pCDNA3.1 (30) into pIRES-Puro vector (Figure S1 in Supplementary Material). GIMAP5v1 was cloned from purified rat $\mathrm{CD}^{+}{ }^{+} \mathrm{T}$ lymphocytes. HEK293T or HeLa cells were transfected using polyethylenimine Max (Polysciences, Inc.) and the stable transfectants were selected using puromycin $(2 \mu \mathrm{g} / \mathrm{ml})$. Protein expression was confirmed by immunofluorescence and by immunoblotting with anti-Flag antibody. The cell lines were cultured in DMEM containing $5 \% \mathrm{FCS}, 1 \%$ pen/strep at $37^{\circ} \mathrm{C}$ in $5 \% \mathrm{CO}_{2}$ containing atmosphere.

\section{Negative Selection of Primary CD4 ${ }^{+}$ T Lymphocytes}

$\mathrm{CD}^{+} \mathrm{T}$ lymphocytes were isolated from human peripheral blood and rat and mouse lymph nodes by negative magnetic selection as described previously $(37,39)$. This study was carried out in accordance with the recommendations of Human Ethics Committee at CRCHUS, Sherbrooke, with written informed consent from all subjects. All subjects gave written informed consent in accordance with the Declaration of Helsinki. The protocol was approved by the "Human Ethics Committee, Centre Hospitalier Université de Sherbrooke (CRCHUS)," Sherbrooke. The protocol number is $14-133$.

\section{RNA Extraction and Quantitative-Reverse Transcription-Polymerase Chain Reaction}

Total RNA was extracted using Trizol reagent (Invitrogen, Thermo Fisher Scientific, Waltham, MA, USA) following the manufacturer's instructions. cDNA was synthesized from $1 \mu \mathrm{g}$ of RNA using QuantiTect Reverse Transcription Kit (Qiagen, Valencia, CA, USA). Quantitative RT-PCR amplification reactions were carried out in iCycler iQ ${ }^{\mathrm{TM}}$ (Bio-Rad, CA) PCR detection systems using $\mathrm{iQ}^{\mathrm{TM}} \mathrm{SYBR}^{\circledR}$ Green Supermix kit (Bio-Rad, Missisauga, ON, Canada). All reactions were run in duplicates along with no template controls for each primer sets. Changes in mRNA expression were calculated using the difference in CT values when compared to housekeeping gene (Gapdh) and expressed relative to controls.

\section{Confocal Microscopy}

Stable HEK293T cell lines expressing the GIMAP5 constructs were grown on $15 \mathrm{~mm}$ coverslips and were transiently cotransfected with EGFP- $\alpha$-tubulin, EYFP-KFC5 (Kinesin), or EGFPIC2-FL (Dynein). Forty-eight hours post-transfection, cells were washed with PBS, fixed with 2\% PFA for 13 min, washed, permeabilized with $0.2 \%$ saponin for $12 \mathrm{~min}$, washed, and blocked for 20 min with $2 \%$ milk in PBS. The slides were incubated with the appropriate primary $\mathrm{Ab}$ overnight at $4^{\circ} \mathrm{C}$. After washing, the slides were stained with flurochrome-conjugated secondary Abs along with DAPI that stains the nucleus. After the final wash, the slides were mounted with VectaShield (Vector Labs) prior to confocal microscopy. Images were acquired using an Olympus $1 \times 81$ FV1000 microscope with a $60 \times$ oil-immersion objective, and image analysis and Pearson coefficient quantification were done using Fluoview Olympus software 3.1.

For live cell microscopy, HEK293T were grown in coverslips for $48 \mathrm{~h}$ before experiments. For purified CD4 T lymphocytes, cells were incubated in RPMI $5 \%$ at $37^{\circ} \mathrm{C}$ for $1 \mathrm{~h}$ in previously coated $25 \mathrm{~mm}$ coverslips with $100 \mu \mathrm{g} / \mathrm{ml}$ of poly-D-lysine for $2 \mathrm{~h}$ at $37^{\circ} \mathrm{C}$

\section{Calcium Measurements}

HEK293T cells grown on $25 \mathrm{~mm}$ coverslips for 24-72 h and purified primary $\mathrm{T}$ lymphocytes plated on poly-L-lysine coated coverslips were loaded with $1 \mu \mathrm{M}$ Fura 2 -AM for $30 \mathrm{~min}$ at $37^{\circ} \mathrm{C}$. Coverslips were washed and deesterified for $20 \mathrm{~min}$ at room temperature in $\mathrm{Ca}^{2+}$ loading buffer $(120 \mathrm{mM} \mathrm{NaCl}$, $1 \mathrm{mM} \mathrm{Na}_{2} \mathrm{HPO}_{4}, 0.5 \mathrm{mM} \mathrm{MgCl}_{2} 6 \mathrm{H}_{2} \mathrm{O}, 5.5 \mathrm{mM}$ glucose, $25 \mathrm{mM}$ HEPES, and $2 \mathrm{mM} \mathrm{CaCl}_{2}, \mathrm{pH} 7.3$ ). Coverslips were then placed in a chamber in an Olympus IX71 microscope (Olympus Canada Inc., Markham, ON, Canada) equipped with a Lambda-DG-4 illuminator (Sutter Instrument Company, Novato, CA, USA). Cytosolic $\mathrm{Ca}^{2+}\left[\mathrm{Ca}^{2+}\right]_{c}$ measurement was done over an average of $50-70$ cells per coverslip per experiment. $\left[\mathrm{Ca}^{2+}\right]_{c}$ was measured at room temperature using two different excitation wavelengths of 340 and $387 \mathrm{~nm}$, and fluorescence emission was monitored at $510 \mathrm{~nm}$ through a $415-570 \mathrm{~nm}$ dichroic mirror using an Evolve ${ }^{\mathrm{TM}}$ EMCCD camera (photometrics, Tucson, AZ, USA). Image digitalization was done using MetaFluor software (Universal Imaging Corporation, Downingtown, PA, USA). In experiments where there was no $\mathrm{Ca}^{2+}$ in the extracellular medium, $0.5 \mathrm{mM}$ EGTA was add to the loading buffer instead of $2 \mathrm{mM} \mathrm{CaCl}_{2}$ to chelate any extracellular $\mathrm{Ca}^{2+}$. Free $\left[\mathrm{Ca}^{2+}\right]_{\mathrm{i}}$ was calculated using the Grynkiewicz method (76).

\section{Western Blot Analysis}

Proteins were extracted from cell lysates by homogenizing in RIPA buffer containing protease inhibitors and carried out as described in Ref. (38).

\section{Statistical Analysis}

Statistical analyses were performed using GraphPad Prism 6.0 (GraphPad Software, Inc.; San Diego, CA, USA). Data are presented as mean \pm SEM. Statistical significance (considered to be relevant when $p<0.05$ ) between two groups was determined by unpaired $t$ test.

\section{AUTHOR CONTRIBUTIONS}

DS and SR planned the experiments, interpreted the data, and wrote the manuscript. FG performed the experiments involving 
human and murine lymphocytes. SI and CL contributed to the analysis of the data and manuscript revision. GB helped with Fura-2 measurements.

\section{FUNDING}

This work was supported by NSERC (Discovery Grant No. 312777) and CIHR (MOP86530) to SR.

\section{SUPPLEMENTARY MATERIAL}

The Supplementary Material for this article can be found online at http://journal.frontiersin.org/article/10.3389/fimmu.2017.00094/ full\#supplementary-material.

FIGURE S1 | Gimap5 constructs. GIMAP5 deletions were made in the C-terminal transmembrane domains by PCR cloning. AlG, AlG1-type guanine nucleotide binding; TM, transmembrane domain. All constructs were tagged at the N-terminus with Flag, RFP, or EGFP tag. Western blot analysis of Flag-tagged GIMAP5 constructs expressed in HEK293T cells.

FIGURE S2 | GIMAP5v2 does not colocalize with Lysotracker Red. EGFP-tagged GIMAP5v2 expressing HEK293T cells lines was labeled with Lysotracker Red that accumulates in the lysosomal lumen and analyzed by confocal microscopy. Bar represents $10 \mu \mathrm{m}$. Co-localization values are expressed as Pearson's coefficient. Representative data from four experiments with three to eight cells analyzed per experiment are shown.

FIGURE S3 | Co-localization of GIMAP5 with tubulin and actin. Stable transfectants of HEK293T cells expressing full-length and transmembranedeletion constructs of GIMAP5 tagged with EGFP were transiently transfected with cherry- $\alpha$-tubulin (A) or labeled with phalloidin (B) and analyzed by confocal microscopy. Bar represents $10 \mu \mathrm{m}$. Colocalization values are expressed as

\section{REFERENCES}

1. Feske S, Giltnane J, Dolmetsch R, Staudt LM, Rao A. Gene regulation mediated by calcium signals in T lymphocytes. Nat Immunol (2001) 2:316-24. doi: $10.1038 / 86318$

2. Malissen B, Gregoire C, Malissen M, Roncagalli R. Integrative biology of $T$ cell activation. Nat Immunol (2014) 15:790-7. doi:10.1038/ni.2959

3. Liou J, Kim ML, Heo WD, Jones JT, Myers JW, Ferrell JE Jr, et al. STIM is a $\mathrm{Ca} 2+$ sensor essential for $\mathrm{Ca} 2+$-store-depletion-triggered $\mathrm{Ca} 2+$ influx. Curr Biol (2005) 15:1235-41. doi:10.1016/j.cub.2005.05.055

4. Roos J, DiGregorio PJ, Yeromin AV, Ohlsen K, Lioudyno M, Zhang S, et al. STIM1, an essential and conserved component of store-operated Ca2+ channel function. J Cell Biol (2005) 169:435-45. doi:10.1083/jcb.200502019

5. Berridge MJ. Inositol trisphosphate and calcium signalling. Nature (1993) 361:315-25. doi:10.1038/361315a0

6. Hogan PG, Lewis RS, Rao A. Molecular basis of calcium signaling in lymphocytes: STIM and ORAI. Annu Rev Immunol (2010) 28:491-533. doi:10.1146/annurev.immunol.021908.132550

7. Feske S. Calcium signalling in lymphocyte activation and disease. Nat Rev Immunol (2007) 7:690-702. doi:10.1038/nri2152

8. Feske S, Gwack Y, Prakriya M, Srikanth S, Puppel SH, Tanasa B, et al. A mutation in Orail causes immune deficiency by abrogating CRAC channel function. Nature (2006) 441:179-85. doi:10.1038/nature04702

9. Valitutti S, Dessing M, Aktories K, Gallati H, Lanzavecchia A. Sustained signaling leading to $\mathrm{T}$ cell activation results from prolonged $\mathrm{T}$ cell receptor occupancy. Role of T cell actin cytoskeleton. J Exp Med (1995) 181:577-84. doi:10.1084/jem.181.2.577

10. Pfeiffer DR, Gunter TE, Eliseev R, Broekemeier KM, Gunter KK. Release of $\mathrm{Ca} 2+$ from mitochondria via the saturable mechanisms and the permeability transition. IUBMB Life (2001) 52:205-12. doi:10.1080/ 15216540152846019
Pearson's coefficient. Representative data from five to six experiments for $(\mathbf{A})$ and from three experiments for (B) with four to eight cells analyzed per experiment are shown.

FIGURE S4 | Co-localization of GIMAP5 with kinesin. Stable transfectants of HEK293T cells expressing FLAG-tagged GIMAP5 constructs were transiently transfected with EYFP-KIF5C (kinesin) for $48 \mathrm{~h}$ and analyzed by confocal microscopy. Bar represents $10 \mu \mathrm{m}$. Colocalization values are expressed as Pearson's coefficient (B). Representative data from three experiments with two to six cells analyzed per experiment are shown.

FIGURE S5 | Absence of co-localization of GIMAP5 with dynein. Stable transfectants of HEK293T cells expressing FLAG-tagged GIMAP5 constructs were transiently transfected with EGFP-IC2-FL (dynein) for $48 \mathrm{~h}$ and analyzed by confocal microscopy (A). Bar represents $10 \mu \mathrm{m}$. Co-localization values are expressed as Pearson's coefficient (B). Representative data from three experiments with two to five cells analyzed per experiment are shown.

VIDEO S1 Movement of GIMAP5v2- and LAMP1-expressing vesicles in HEK293T cells. Stable transfectants of HEK293T cells expressing EGFP-tagged GIMAP5V2 were transiently transfected with cherry-Lamp1. Cells were viewed under 100x epifluorescence microscope for $538 \mathrm{~s}$. In Video S2 in Supplementary Material, cells stable transfected for EGFP-GIMAP5 can be seen and the cell on the left shows the transient transfection for cherry-Lamp1 only.

\section{VIDEO S2 | Movement of GIMAP5v2} transfectants of HEK293T cells expressing RFP-tagged GIMAP5V2 $\Delta$ TM were followed for $5 \mathrm{~min}$. Distribution of RFP-GIMAP5 $\Delta$ TM seems homogenous and diffuse.

\section{VIDEO S3 | GIMAP5v2-expressing vesicles move along microtubules.}

HeLa cells were transiently transfected with vectors containing cherry- $\alpha$ tubulin and EGFP-tagged GIMAP5v2. The vesicles are either filamentous or spherical. The speed of their movement is not uniform. Snapshots of the movement are shown in Figure 4.

11. Hoth M, Fanger CM, Lewis RS. Mitochondrial regulation of store-operated calcium signaling in T lymphocytes. J Cell Biol (1997) 137:633-48. doi:10.1083/jcb.137.3.633

12. Hajnoczky G, Csordas G, Yi M. Old players in a new role: mitochondriaassociated membranes, VDAC, and ryanodine receptors as contributors to calcium signal propagation from endoplasmic reticulum to the mitochondria. Cell Calcium (2002) 32:363-77. doi:10.1016/S0143416002001872

13. Jackson R, Rassi N, Crump T, Haynes B, Eisenbarth GS. The BB diabetic rat. Profound T-cell lymphocytopenia. Diabetes (1981) 30:887-9. doi:10.2337/ diab.30.10.887

14. Poussier P, Nakhooda AF, Falk JA, Lee C, Marliss EB. Lymphopenia and abnormal lymphocyte subsets in the "BB" rat: relationship to the diabetic syndrome. Endocrinology (1982) 110:1825-7. doi:10.1210/endo-110-5-1825

15. Elder ME, Maclaren NK. Identification of profound peripheral $\mathrm{T}$ lymphocyte immunodeficiencies in the spontaneously diabetic BB rat. J Immunol (1983) 130:1723-31.

16. Ramanathan S, Poussier P. BB rat lyp mutation and type 1 diabetes. Immunol Rev (2001) 184:161-71. doi:10.1034/j.1600-065x.2001.1840115.x

17. Groen H, Klatter FA, Brons NH, Wubbena AS, Nieuwenhuis P, Kampinga $\mathrm{J}$. High-frequency, but reduced absolute numbers of recent thymic migrants among peripheral blood $\mathrm{T}$ lymphocytes in diabetes-prone BB rats. Cell Immunol (1995) 163:113-9. doi:10.1006/cimm.1995.1105

18. Zadeh HH, Greiner DL, Wu DY, Tausche F, Goldschneider I. Abnormalities in the export and fate of recent thymic emigrants in diabetes-prone BB/W rats. Autoimmunity (1996) 24:35-46. doi:10.3109/0891693960 8995355

19. Ramanathan S, Norwich K, Poussier P. Antigen activation rescues recent thymic emigrants from programmed cell death in the BB rat. J Immunol (1998) 160:5757-64.

20. Hernandez-Hoyos G, Joseph S, Miller NG, Butcher GW. The lymphopenia mutation of the $\mathrm{BB}$ rat causes inappropriate apoptosis of 
mature thymocytes. Eur J Immunol (1999) 29:1832-41. doi:10.1002/ (SICI)1521-4141(199906)29:06<1832::AID-IMMU1832>3.3.CO;2-6

21. Hornum L, Romer J, Markholst H. The diabetes-prone BB rat carries a frameshift mutation in Ian4, a positional candidate of Iddm1. Diabetes (2002) 51:1972-9. doi:10.2337/diabetes.51.6.1972

22. MacMurray AJ, Moralejo DH, Kwitek AE, Rutledge EA, Van Yserloo B, Gohlke $\mathrm{P}$, et al. Lymphopenia in the $\mathrm{BB}$ rat model of type 1 diabetes is due to a mutation in a novel immune-associated nucleotide (Ian)-related gene. Genome Res (2002) 12:1029-39. doi:10.1101/gr.412702

23. Krucken J, Schroetel RM, Muller IU, Saidani N, Marinovski P, Benten WP, et al. Comparative analysis of the human gimap gene cluster encoding a novel GTPase family. Gene (2004) 341:291-304. doi:10.1016/j.gene. 2004.07.005

24. Liu C, Wang T, Zhang W, Li X. Computational identification and analysis of immune-associated nucleotide gene family in Arabidopsis thaliana. J Plant Physiol (2008) 165:777-87. doi:10.1016/j.jplph.2007.06.002

25. Nitta T, Nasreen M, Seike T, Goji A, Ohigashi I, Miyazaki T, et al. IAN family critically regulates survival and development of T lymphocytes. PLoS Biol (2006) 4:e103. doi:10.1371/journal.pbio.0040103

26. Zenz T, Roessner A, Thomas A, Frohling S, Dohner H, Calabretta B, et al. hIan5: the human ortholog to the rat Ian4/Iddm1/lyp is a new member of the Ian family that is overexpressed in B-cell lymphoid malignancies. Genes Immun (2004) 5:109-16. doi:10.1038/sj.gene.6364044

27. Barnes MJ, Aksoylar H, Krebs P, Bourdeau T, Arnold CN, Xia Y, et al. Loss of $\mathrm{T}$ cell and $\mathrm{B}$ cell quiescence precedes the onset of microbial flora-dependent wasting disease and intestinal inflammation in Gimap5-deficient mice. J Immunol (2010) 184:3743-54. doi:10.4049/jimmunol.0903164

28. Chen Y, Yu M, Dai X, Zogg M, Wen R, Weiler H, et al. Critical role for Gimap5 in the survival of mouse hematopoietic stem and progenitor cells. J Exp Med (2011) 208:923-35. doi:10.1084/jem.20101192

29. Pino SC, O'Sullivan-Murphy B, Lidstone EA, Yang C, Lipson KL, Jurczyk A, et al. CHOP mediates endoplasmic reticulum stress-induced apoptosis in Gimap5-deficient T cells. PLoS One (2009) 4:e5468. doi:10.1371/journal. pone. 0005468

30. Keita M, Leblanc C, Andrews D, Ramanathan S. GIMAP5 regulates mitochondrial integrity from a distinct subcellular compartment. Biochem Biophys Res Commun (2007) 361:481-6. doi:10.1016/j.bbrc.2007.07.048

31. Pandarpurkar M, Wilson-Fritch L, Corvera S, Markholst H, Hornum $\mathrm{L}$, Greiner DL, et al. Ian4 is required for mitochondrial integrity and T cell survival. Proc Natl Acad Sci U S A (2003) 100:10382-7. doi:10.1073/ pnas. 1832170100

32. Maraskovsky E, Teepe M, Morrissey PJ, Braddy S, Miller RE, Lynch DH, et al. Impaired survival and proliferation in IL-7 receptor-deficient peripheral T cells. J Immunol (1996) 157:5315-23.

33. Takeda S, Rodewald HR, Arakawa H, Bluethmann H, Shimizu T. MHC class II molecules are not required for survival of newly generated CD4+ T cells, but affect their long-term life span. Immunity (1996) 5:217-28. doi:10.1016/ S1074-7613(00)80317-9

34. Revy P, Sospedra M, Barbour B, Trautmann A. Functional antigen-independent synapses formed between T cells and dendritic cells. Nat Immunol (2001) 2:925-31. doi:10.1038/ni713

35. Seddon B, Tomlinson P, Zamoyska R. Interleukin 7 and $\mathrm{T}$ cell receptor signals regulate homeostasis of CD4 memory cells. Nat Immunol (2003) 4:680-6. doi:10.1038/ni946

36. Wei SH, Safrina O, Yu Y, Garrod KR, Cahalan MD, Parker I. Ca2+ signals in $\mathrm{CD} 4+\mathrm{T}$ cells during early contacts with antigen-bearing dendritic cells in lymph node. J Immunol (2007) 179:1586-94. doi:10.4049/ jimmunol.179.3.1586

37. Chen XL, Serrano D, Ghobadi F, Mayhue M, Hoebe K, Ilangumaran S, et al. TCR and IL-7 signaling are altered in the absence of functional GTPase of the immune associated nucleotide binding protein 5 (GIMAP5). PLoS One (2016) 11:e0151837. doi:10.1371/journal.pone.0151837

38. Chen XL, Serrano D, Mayhue M, Hoebe K, Ilangumaran S, Ramanathan S. GIMAP5 deficiency is associated with increased AKT activity in T lymphocytes. PLoS One (2015) 10:e0139019. doi:10.1371/journal.pone. 0139019

39. Ilangumaran S, Forand-Boulerice M, Bousquet SM, Savard A, Rocheleau P, Chen XL, et al. Loss of GIMAP5 (GTPase of immunity-associated nucleotide binding protein 5) impairs calcium signaling in rat T lymphocytes. $\mathrm{Mol}$ Immunol (2009) 46:1256-9. doi:10.1016/j.molimm.2008.09.031

40. Chen XL, Serrano D, Mayhue M, Wieden HJ, Stankova J, Boulay G, et al. GTPase of the immune-associated nucleotide-binding protein 5 (GIMAP5) regulates calcium influx in T-lymphocytes by promoting mitochondrial calcium accumulation. Biochem J (2013) 449:353-64. doi:10.1042/ BJ20120516

41. Wong VWY, Saunders AE, Hutchings A, Pascall JC, Carter C, Bright NA, et al. The autoimmunity-related GIMAP5 GTPase is a lysosome-associated protein. Self Nonself (2010) 1:259-68. doi:10.4161/self.1.3.12819

42. Hancock WO. Bidirectional cargo transport: moving beyond tug of war. Nat Rev Mol Cell Biol (2014) 15:615-28. doi:10.1038/nrm3853

43. Wade RH, Kozielski F. Structural links to kinesin directionality and movement. Nat Struct Biol (2000) 7:456-60. doi:10.1038/75850

44. Haller T, Dietl P, Deetjen P, Volkl H. The lysosomal compartment as intracellular calcium store in MDCK cells: a possible involvement in InsP3-mediated Ca2+ release. Cell Calcium (1996) 19:157-65. doi:10.1016/ S0143-4160(96)90084-6

45. Zbidi H, Jardin I, Woodard GE, Lopez JJ, Berna-Erro A, Salido GM, et al. STIM1 and STIM2 are located in the acidic Ca2+ stores and associates with Orail upon depletion of the acidic stores in human platelets. J Biol Chem (2011) 286:12257-70. doi:10.1074/jbc.M110.190694

46. Garrity AG, Wang W, Collier CM, Levey SA, Gao Q, Xu H. The endoplasmic reticulum, not the $\mathrm{pH}$ gradient, drives calcium refilling of lysosomes. Elife (2016) 5:e15887. doi:10.7554/eLife.15887

47. Lopez Sanjurjo CI, Tovey SC, Taylor CW. Rapid recycling of Ca2+ between IP3-sensitive stores and lysosomes. PLoS One (2014) 9:e111275. doi:10.1371/ journal.pone.0111275

48. Quintana A, Schwarz EC, Schwindling C, Lipp P, Kaestner L, Hoth M. Sustained activity of calcium release-activated calcium channels requires translocation of mitochondria to the plasma membrane. J Biol Chem (2006) 281:40302-9. doi:10.1074/jbc.M607896200

49. Morgan AJ, Platt FM, Lloyd-Evans E, Galione A. Molecular mechanisms of endolysosomal Ca2+ signalling in health and disease. Biochem J (2011) 439:349-74. doi:10.1042/BJ20110949

50. Davis LC, Morgan AJ, Chen JL, Snead CM, Bloor-Young D, Shenderov E, et al. NAADP activates two-pore channels on T cell cytolytic granules to stimulate exocytosis and killing. Curr Biol (2012) 22:2331-7. doi:10.1016/j. cub.2012.10.035

51. Andersen UN, Markholst H, Hornum L. The antiapoptotic gene Ian4l1 in the rat: genomic organization and promoter characterization. Gene (2004) 341:141-8. doi:10.1016/j.gene.2004.06.034

52. Yano K, Carter C, Yoshida N, Abe T, Yamada A, Nitta T, et al. Gimap3 and Gimap5 cooperate to maintain T-cell numbers in the mouse. Eur J Immunol (2014) 44:561-72. doi:10.1002/eji.201343750

53. Schwefel D, Arasu BS, Marino SF, Lamprecht B, Kochert K, Rosenbaum E, et al. Structural insights into the mechanism of GTPase activation in the GIMAP family. Structure (2013) 21:550-9. doi:10.1016/j.str.2013. 01.014

54. Finetti F, Patrussi L, Masi G, Onnis A, Galgano D, Lucherini OM, et al. Specific recycling receptors are targeted to the immune synapse by the intraflagellar transport system. J Cell Sci (2014) 127:1924-37. doi:10.1242/ jcs. 139337

55. Willinger T, Staron M, Ferguson SM, De Camilli P, Flavell RA. Dynamin 2-dependent endocytosis sustains $\mathrm{T}$-cell receptor signaling and drives metabolic reprogramming in T lymphocytes. Proc Natl Acad Sci U S A (2015) 112:4423-8. doi:10.1073/pnas.1504279112

56. Gorska MM, Liang Q, Karim Z, Alam R. Uncoordinated 119 protein controls trafficking of Lck via the Rab11 endosome and is critical for immunological synapse formation. J Immunol (2009) 183:1675-84. doi:10.4049/ jimmunol.0900792

57. Roy SG, Stevens MW, So L, Edinger AL. Reciprocal effects of rab7 deletion in activated and neglected T cells. Autophagy (2013) 9:1009-23. doi:10.4161/ auto. 24468

58. Pascall JC, Rotondo S, Mukadam AS, Oxley D, Webster J, Walker SA, et al. The immune system GTPase GIMAP6 interacts with the Atg8 homologue GABARAPL2 and is recruited to autophagosomes. PLoS One (2013) 8:e77782. doi:10.1371/journal.pone.0077782 
59. Castaneda JA, Lim MJ, Cooper JD, Pearce DA. Immune system irregularities in lysosomal storage disorders. Acta Neuropathol (2008) 115:159-74. doi:10.1007/s00401-007-0296-4

60. Baixauli F, Acin-Perez R, Villarroya-Beltri C, Mazzeo C, Nunez-Andrade N, Gabande-Rodriguez E, et al. Mitochondrial respiration controls lysosomal function during inflammatory T cell responses. Cell Metab (2015) 22:485-98. doi:10.1016/j.cmet.2015.07.020

61. Quintana A, Hoth M. Mitochondrial dynamics and their impact on T cell function. Cell Calcium (2012) 52:57-63. doi:10.1016/j.ceca.2012.02.005

62. Quintana A, Schwindling C, Wenning AS, Becherer U, Rettig J, Schwarz $\mathrm{EC}$, et al. $\mathrm{T}$ cell activation requires mitochondrial translocation to the immunological synapse. Proc Natl Acad Sci U S A (2007) 104:14418-23. doi:10.1073/pnas.0703126104

63. Penny CJ, Kilpatrick BS, Han JM, Sneyd J, Patel S. A computational model of lysosome-ER Ca2+ microdomains. J Cell Sci (2014) 127:2934-43. doi:10.1242/jcs. 149047

64. Ronco V, Potenza DM, Denti F, Vullo S, Gagliano G, Tognolina M, et al. A novel $\mathrm{Ca}(2)(+)$-mediated cross-talk between endoplasmic reticulum and acidic organelles: implications for NAADP-dependent $\mathrm{Ca}(2)(+)$ signalling. Cell Calcium (2015) 57:89-100. doi:10.1016/j.ceca.2015.01.001

65. Giacomello M, Drago I, Bortolozzi M, Scorzeto M, Gianelle A, Pizzo $\mathrm{P}$, et al. $\mathrm{Ca} 2+$ hot spots on the mitochondrial surface are generated by $\mathrm{Ca} 2+$ mobilization from stores, but not by activation of store-operated Ca2+ channels. Mol Cell (2010) 38:280-90. doi:10.1016/j.molcel.2010. 04.003

66. Kilpatrick BS, Eden ER, Schapira AH, Futter CE, Patel S. Direct mobilisation of lysosomal Ca2+ triggers complex Ca2+ signals. J Cell Sci (2013) 126:60-6. doi:10.1242/jcs. 118836

67. Morgan AJ, Davis LC, Wagner SK, Lewis AM, Parrington J, Churchill GC, et al. Bidirectional $\mathrm{Ca}(2)(+)$ signaling occurs between the endoplasmic reticulum and acidic organelles. J Cell Biol (2013) 200:789-805. doi:10.1083/ jcb. 201204078

68. Elbaz-Alon Y, Rosenfeld-Gur E, Shinder V, Futerman AH, Geiger T, Schuldiner M. A dynamic interface between vacuoles and mitochondria in yeast. Dev Cell (2014) 30:95-102. doi:10.1016/j.devcel.2014.06.007

69. Aksoylar HI, Lampe K, Barnes MJ, Plas DR, Hoebe K. Loss of immunological tolerance in Gimap5-deficient mice is associated with loss of Foxo in CD4+ T cells. J Immunol (2012) 188:146-54. doi:10.4049/jimmunol. 1101206

70. Steigemann P, Wurzenberger C, Schmitz MH, Held M, Guizetti J, Maar S, et al. Aurora B-mediated abscission checkpoint protects against tetraploidization. Cell (2009) 136:473-84. doi:10.1016/j.cell.2008.12.020

71. Honey K, Rudensky AY. Lysosomal cysteine proteases regulate antigen presentation. Nat Rev Immunol (2003) 3:472-82. doi:10.1038/nri1110

72. Zoncu R, Bar-Peled L, Efeyan A, Wang S, Sancak Y, Sabatini DM. mTORC1 senses lysosomal amino acids through an inside-out mechanism that requires the vacuolar $\mathrm{H}(+)$-ATPase. Science (2011) 334:678-83. doi:10.1126/ science. 1207056

73. Smith MJ, Pozo K, Brickley K, Stephenson FA. Mapping the GRIF-1 binding domain of the kinesin, KIF5C, substantiates a role for GRIF-1 as an adaptor protein in the anterograde trafficking of cargoes. $\mathrm{J}$ Biol Chem (2006) 281:27216-28. doi:10.1074/jbc.M600522200

74. Lachance V, Angers S, Parent JL. New insights in the regulation of Rab GTPases by G protein-coupled receptors. Small GTPases (2014) 5:e29039. doi:10.4161/sgtp.29039

75. Cayouette S, Bousquet SM, Francoeur N, Dupre E, Monet M, Gagnon H, et al. Involvement of Rab9 and Rab11 in the intracellular trafficking of TRPC6. Biochim Biophys Acta (2010) 1803:805-12. doi:10.1016/j.bbamcr.2010. 03.010

76. Grynkiewicz G, Poenie M, Tsien RY. A new generation of Ca2+ indicators with greatly improved fluorescence properties. J Biol Chem (1985) 260:3440-50

Conflict of Interest Statement: The authors declare that the research was conducted in the absence of any commercial or financial relationships that could be construed as a potential conflict of interest.

Copyright (c) 2017 Serrano, Ghobadi, Boulay, Ilangumaran, Lavoie and Ramanathan. This is an open-access article distributed under the terms of the Creative Commons Attribution License (CC BY). The use, distribution or reproduction in other forums is permitted, provided the original author(s) or licensor are credited and that the original publication in this journal is cited, in accordance with accepted academic practice. No use, distribution or reproduction is permitted which does not comply with these terms. 